\section{Pacific Northwest}

National Laboratory

Operated by Battelle for the

U.S. Department of Energy

\title{
Third Quarter Hanford Seismic Report for Fiscal Year 2003
}

Pacific Northwest National Laboratory Seismic Monitoring Team

September 2003

Prepared for the U.S. Department of Energy

under Contract DE-AC06-76RL01830 


\title{
DISCLAIMER
}

This report was prepared as an account of work sponsored by an agency of the United States Government. Reference herein to any specific commercial product, process, or service by trade name, trademark, manufacturer, or otherwise does not necessarily constitute or imply its endorsement, recommendation, or favoring by the United States Government or any agency thereof, or Battelle Memorial Institute.

\author{
PACIFIC NORTHWEST NATIONAL LABORATORY \\ operated by \\ BATTELLE \\ for the \\ UNITED STATES DEPARTMENT OF ENERGY \\ under Contract DE-AC06-76RL01830
}

\begin{abstract}
Printed in the United States of America
Available to DOE and DOE contractors from the

Office of Scientific and Technical Information, P.O. Box 62, Oak Ridge, TN 37831:

prices available from (615) 576-8401.

Available to the public from the National Technical Information Service, U.S. Department of Commerce, 5285 Port Royal Rd., Springfield, VA 22161
\end{abstract}




\section{Third Quarter Hanford Seismic Report for Fiscal Year 2003}

D. C. Hartshorn

S. P. Reidel

A. C. Rohay

September 2003

Prepared for

the U.S. Department of Energy

under Contract DE-AC06-76RLO 1830

Pacific Northwest National Laboratory

Richland, Washington 99352 


\section{Summary}

Hanford Seismic Monitoring provides an uninterrupted collection of high-quality raw and processed seismic data from the Hanford Seismic Network for the U.S. Department of Energy and its contractors. Hanford Seismic Monitoring also locates and identifies sources of seismic activity and monitors changes in the historical pattern of seismic activity at the Hanford Site. The data are compiled, archived, and published for use by the Hanford Site for waste management, Natural Phenomena Hazards assessments, and engineering design and construction. In addition, the seismic monitoring organization works with the Hanford Site Emergency Services Organization to provide assistance in the event of a significant earthquake on the Hanford Site.

The Hanford Seismic Network and the Eastern Washington Regional Network consist of 41 individual sensor sites and 15 radio relay sites maintained by the Hanford Seismic Monitoring staff.

For the Hanford Seismic Network, there were 356 triggers during the third quarter of fiscal year 2003. Of these triggers, 141 were earthquakes.

Thirty-four earthquakes of the 141 earthquakes were located in the Hanford Seismic Network area. Stratigraphically 15 occurred in the Columbia River basalt, 13 were earthquakes in the pre-basalt sediments, and 6 were earthquakes in the crystalline basement. Geographically, 22 earthquakes occurred in swarm areas, 1 earthquake was associated with a major geologic structure, and 11 were classified as random events.

During the third quarter, an earthquake swarm consisting of 15 earthquakes occurred on the south limb of Rattlesnake Mountain. The earthquakes are centered over the northwest extension of the Horse Heaven Hills anticline and probably occur at the base of the Columbia River Basalt Group. 


\section{Acronyms}

\begin{tabular}{|c|c|}
\hline BWIP & Basalt Waste Isolation Project \\
\hline CDPD & Cellular Digital Packet Data \\
\hline CRBG & Columbia River Basalt Group \\
\hline DOE & U.S. Department of Energy \\
\hline ETNA & strong motion accelerometer manufactured by Kinemetrics \\
\hline EWRN & Eastern Washington Regional Network \\
\hline FY & fiscal year \\
\hline GPS & Global Positioning System \\
\hline HSN & Hanford Seismic Network \\
\hline $\mathrm{M}_{\mathrm{c}}$ & Coda Length Magnitude \\
\hline $\mathrm{M}_{\mathrm{L}}$ & Local Magnitude \\
\hline $\mathrm{M}_{\mathrm{w}}$ & Moment Magnitude \\
\hline PNNL & Pacific Northwest National Laboratory \\
\hline RAW & Rattlesnake Mountain-Wallula Alignment \\
\hline SMA & strong motion accelerometer \\
\hline USGS & United States Geological Survey \\
\hline UTC & Universal Time, Coordinated \\
\hline UW & University of Washington \\
\hline WHC & Westinghouse Hanford Company \\
\hline
\end{tabular}




\section{Contents}

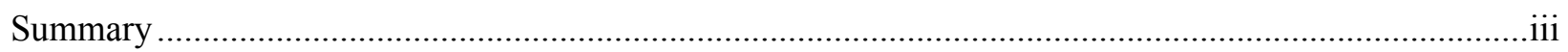

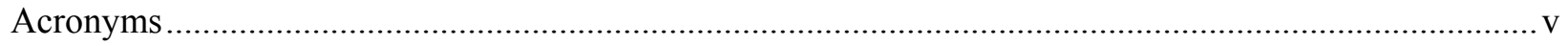

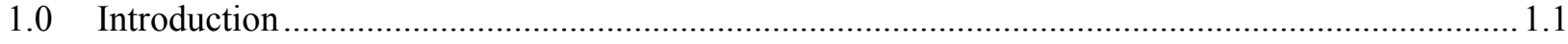

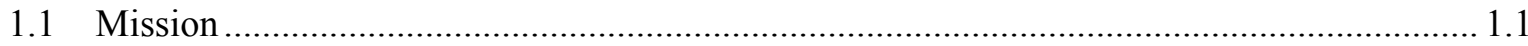

1.2 History of Seismic Monitoring at Hanford........................................................................ 1.1

1.3 Documentation and Reports ……………………………............................................... 1.2

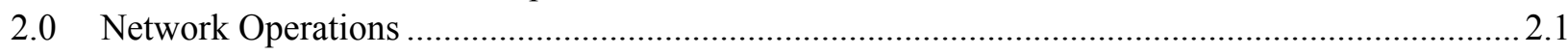

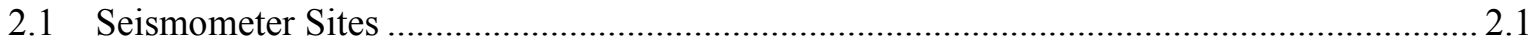

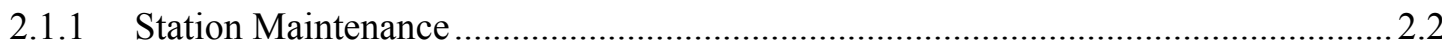

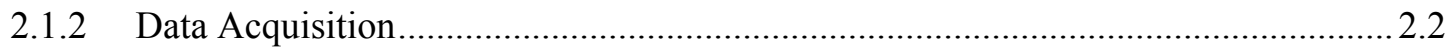

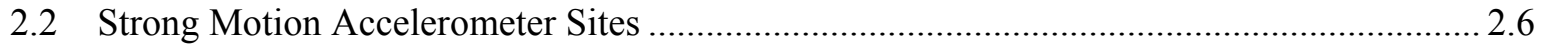

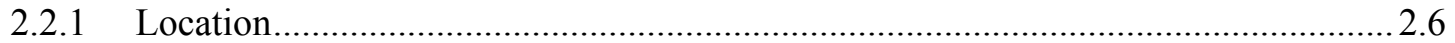

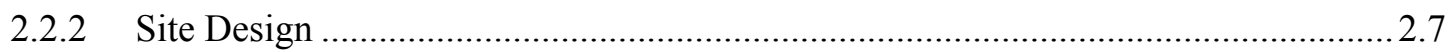

2.2.3 Strong Motion Accelerometer Operations Center ..................................................2. 2.8

2.2.4 Strong Motion Operational Characteristics ……………………………………....... 2.8

3.0 Earthquake Catalog Description............................................................................................ 3.1

3.1 Coda Length Magnitude ............................................................................................... 3.1

3.2 Velocity Model............................................................................................................. 3.1

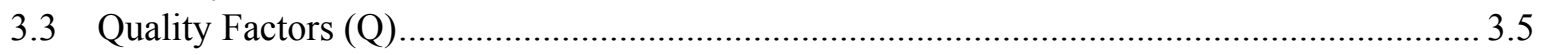

$4.0 \quad$ Geology and Tectonic Analysis ........................................................................................ 4.1

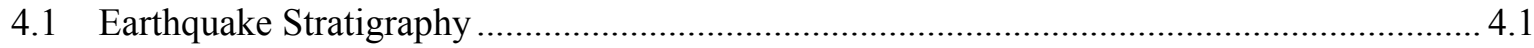

4.2 Geologic Structure Beneath the Monitored Area .................................................................. 4.1

4.3 Tectonic Pattern......................................................................................................... 4.4

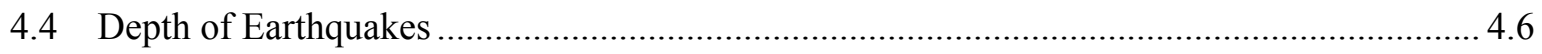

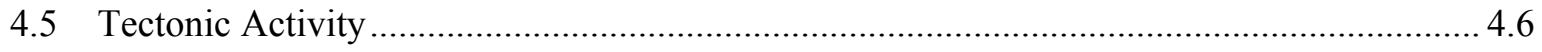

4.5.1 Third Quarter Summary ………………………………………………………. 4.6

4.5.2 Third Quarter Earthquakes of FY 2003 …………………………………..... 4.8

5.0 Strong Motion Accelerometer Operations …………………………………………………... 5.1

5.1 Third Quarter of FY 2003 Triggers of the Hanford SMA Network ......................................5.1

6.0 Capabilities in the Event of a Significant Earthquake.................................................................... 6.1

6.1 Use of the SMA Network in the Event of an Earthquake ………........................................ 6.1

$7.0 \quad$ References ..................................................................................................................... 


\section{Figures}

2.1 Locations of Seismograph Stations and Strong Motion Accelerometer Sites in the

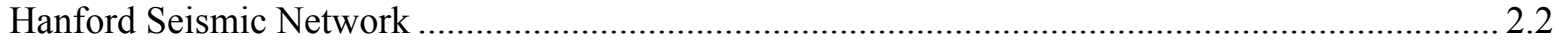

2.2 Locations of Seismograph Stations in the Eastern Washington Regional Network ....................... 2.4

2.3 Schematic Diagram of a Strong Motion Accelerometer Installation............................................... 2.8

4.1 Tectonic Map of Columbia Basin Showing Major Seismic Source Structures ............................... 4.2

4.2 Geologic Cross Sections Through the Columbia Basin ............................................................. 4.3

4.3 Locations of Known Earthquake Swarm Areas in the Hanford Monitoring Network Area............. 4.5

4.4 All Earthquakes Recorded in the Hanford Monitoring Area Between May 1, 2003 and June 30, 2003

\section{Tables}

2.1 Seismic Stations in the Hanford Seismic Network ................................................................... 2.1

2.2 Seismic Stations in the Eastern Washington Regional Network ................................................... 2.3

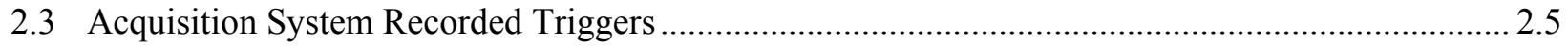

2.4 Free-Field Strong Motion Accelerometer Sites ...................................................................... 2.6

2.5 Instrument Parameters for the Kinemetrics ETNA ${ }^{\text {TM }}$ System in the Hanford SMA Network .......... 2.7

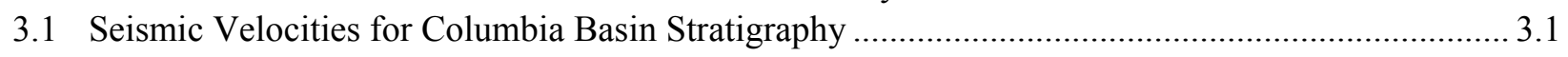

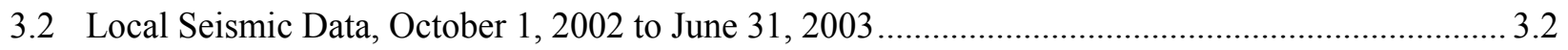

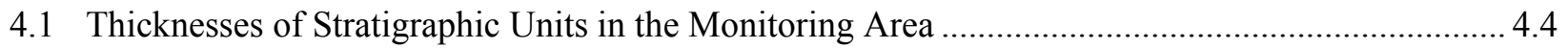

4.2 Number of Local Earthquakes Occurring in Stratigraphic Units ............................................... 4.6

4.3 Summary of Earthquake Locations for FY 2003 …................................................................ 4.6 


\subsection{Introduction}

This report covers seismic activity on and near the Hanford Site for the third quarter of fiscal year (FY) 2003. The report includes earthquake activity that occurred between April 1, 2003 and June 31, 2003 and the geologic interpretation of the sources of the earthquakes.

\subsection{Mission}

The principal mission of Hanford Seismic Monitoring at the Hanford Site is to insure compliance with DOE Order 420.1, "Facility Safety" and DOE Order G 420.1-1, Section 4.7, "Emergency Preparedness and Emergency Communications." DOE Order 420.1 establishes facility safety requirements related to nuclear safety design, criticality safety, fire protection, and natural phenomena hazards mitigation. For seismic monitoring, this order states:

\subsubsection{Natural Phenomena Detection.}

Facilities or sites with hazardous materials shall have instrumentation or other means to detect and record the occurrence and severity of seismic events.

The Seismic Monitoring Project supports Hanford Site emergency services organizations in complying with DOE Order G 420.1-1, Section 4.7, "Emergency Preparedness and Emergency Communications," by providing assistance in the event of an earthquake on the Hanford Site.

In addition, seismic monitoring provides an uninterrupted collection of high-quality raw seismic data from the Hanford Seismic Network (HSN) located on and around the Hanford Site, and the Eastern Washington Regional Network (EWRN). This report provides interpretations of seismic events from the Hanford Site and vicinity. Hanford Seismic Monitoring locates and identifies sources of seismic activity, monitors changes in the historical pattern of seismic activity at the Hanford Site, and builds a "local" earthquake database (processed data) that is permanently archived. The focus of this report is the precise location of earthquakes proximal to or on the Hanford Site, specifically between 46 degrees and 47 degrees north latitude and between 119 degrees and 120 degrees west longitude. Data from the EWRN and other seismic networks in the northwest provide the Seismic Monitoring Project with necessary regional input for the seismic hazards analysis at the Hanford Site. These seismic data are used to support Hanford Site contractors for waste management activities, Natural Phenomena Hazards assessments, and engineering design and construction.

\subsection{History of Seismic Monitoring at Hanford}

Seismic monitoring at the Hanford Site was established in 1969 by the United States Geological Survey (USGS) under a contract with the U.S. Atomic Energy Commission. In 1975, the University of Washington (UW) assumed responsibility for the network and subsequently expanded it. In 1979, the Basalt Waste Isolation Project (BWIP) became responsible for collecting seismic data for the Hanford Site as part of site characterization activities. Rockwell Hanford Operations, followed by Westinghouse Hanford Company (WHC), operated the local network and were the contract technical advisors for the EWRN operated and maintained by UW. Funding ended for BWIP in December 1988. Seismic monitoring and 
responsibility for the UW contract were then transferred to WHC's Environmental Division. Maintenance responsibilities for the EWRN also were assigned to WHC who made major upgrades to EWRN sites.

Effective October 1, 1996, seismic monitoring was transferred to the Pacific Northwest National Laboratory (PNNL). ${ }^{\text {(a) }}$ Seismic monitoring is part of PNNL's Applied Geology and Geochemistry Group, Environmental Technology Division.

The Hanford Strong Motion Accelerometer (SMA) network was constructed during 1997 and came on line in May 1997. It operated continuously until September 30, 1997 when it was mothballed due to lack of funding. Funding was restored on October 1, 1998 by joint agreement between the U.S. Depart-

ment of Energy (DOE) and PNNL. Operation of the free-field sites resumed on November 20, 1999 and has operated continuously since that time.

\subsection{Documentation and Reports}

The Seismic Monitoring Project issues quarterly reports of local activity, an annual catalog of earthquake activity on and near the Hanford Site, and special-interest bulletins on local seismic events. The annual catalog includes the fourth quarter report for the fiscal year. Hanford Seismic Monitoring also provides information and special reports to other functions as requested. Earthquake information provided in these reports is subject to revisions if new data become available. In addition, an archive of all seismic data from the HSN is maintained by PNNL.

(a) Pacific Northwest National Laboratory is operated by Battelle Memorial Institute for the U.S. Department of Energy. 


\subsection{Network Operations}

\subsection{Seismometer Sites}

The seismic monitoring network consists of two designs of equipment and sites: seismometer sites and strong motion accelerometer (SMA) sites. Seismometer sites are designed to locate earthquakes and determine their magnitude and hypocenter location. SMA sites are designed to measure ground motion.

The HSN and the EWRN consist of 41 sensor sites. Most sites are in remote locations and require solar panels and batteries for power. The HSN uses 21 sites (Table 2.1 and Figure 2.1) and the EWRN uses 35 sites (Table 2.2 and Figure 2.2); both networks share 16 sites. The networks have 45 combined data channels because Gable Butte and Frenchman Hills East are three-component sites, each consisting of one vertical, one north-south horizontal, and one east-west horizontal data channel. Both networks use 15 additional telemetry relay sites. Data from all sites or relays are transmitted to the Sigma V building, Richland, Washington.

Table 2.1. Seismic Stations in the Hanford Seismic Network

\begin{tabular}{|c|c|c|c|c|}
\hline Station & $\begin{array}{c}\text { Latitude } \\
\text { Deg. Min. N }\end{array}$ & $\begin{array}{c}\text { Longitude } \\
\text { Deg. Min. W }\end{array}$ & Elevation (m) & Station Name \\
\hline BEN & $46 \mathrm{~N} 31.13$ & $119 \mathrm{~W} 43.02$ & 340 & Benson Ranch \\
\hline BRV & $46 \mathrm{~N} 49.12$ & 119W59.47 & 920 & Black Rock Valley \\
\hline BVW & $46 \mathrm{~N} 48.66$ & 119W52.99 & 670 & Beverly \\
\hline CRF & $46 \mathrm{~N} 49.50$ & 119W23.22 & 189 & Corfu \\
\hline ET3 & $46 \mathrm{~N} 34.64$ & $118 \mathrm{~W} 56.25$ & 286 & Eltopia Three \\
\hline *FHE & $46 \mathrm{~N} 57.11$ & 119W29.82 & 455 & Frenchman Hills East \\
\hline$*$ GBB & 46N36.49 & $119 \mathrm{~W} 37.62$ & 177 & Gable Butte \\
\hline GBL & $46 \mathrm{~N} 35.92$ & 119W27.58 & 330 & Gable Mountain \\
\hline $\mathrm{H} 2 \mathrm{O}$ & $46 \mathrm{~N} 23.75$ & 119W25.38 & 158 & Water \\
\hline LOC & $46 \mathrm{~N} 43.02$ & $119 \mathrm{~W} 25.85$ & 210 & Locke Island \\
\hline MDW & 46N36.79 & 119W45.66 & 330 & Midway \\
\hline MJ2 & $46 \mathrm{~N} 33.45$ & 119W21.54 & 146 & May Junction Two \\
\hline OT3 & $46 \mathrm{~N} 40.14$ & 119W13.98 & 322 & Othello Three \\
\hline PRO & $46 \mathrm{~N} 12.73$ & 119W41.15 & 550 & Prosser \\
\hline RED & $46 \mathrm{~N} 17.92$ & $119 \mathrm{~W} 26.30$ & 366 & Red Mountain \\
\hline RSW & $46 \mathrm{~N} 23.67$ & 119W35.48 & 1,045 & Rattlesnake Mountain \\
\hline SNI & $46 \mathrm{~N} 27.85$ & $119 \mathrm{~W} 39.60$ & 312 & Snively Ranch \\
\hline WA2 & $46 \mathrm{~N} 45.32$ & 119W33.94 & 244 & Wahluke Slope \\
\hline WIW & $46 \mathrm{~N} 25.76$ & $119 \mathrm{~W} 17.26$ & 128 & Wooded Island \\
\hline WRD & $46 \mathrm{~N} 58.20$ & 119W08.69 & 375 & Warden \\
\hline YPT & $46 \mathrm{~N} 02.93$ & $118 \mathrm{~W} 57.73$ & 325 & Yellepit \\
\hline
\end{tabular}




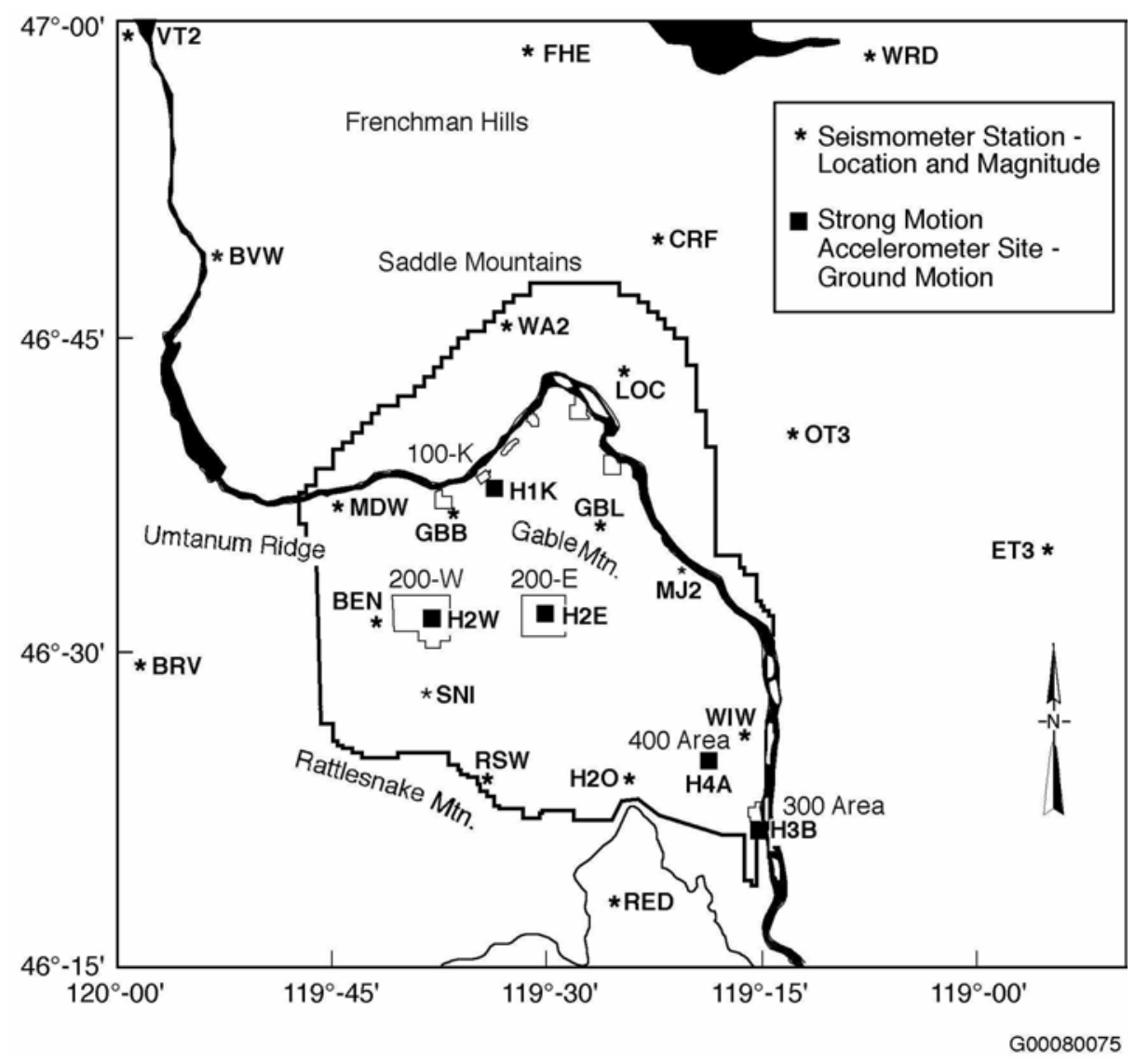

Figure 2.1. Locations of Seismograph Stations and Strong Motion Accelerometer Sites in the Hanford Seismic Network (see Table 2.1 for description of locations). Locations for Prosser (PRO) and Yellepit (YPT) are not shown. See Figure 2.2 for the locations of those sites.

\subsubsection{Station Maintenance}

The HSN's maintenance records for the seismic sensor and relay sites are on file in the Hanford Seismic Monitoring office, Sigma V Building, Richland Washington.

\subsubsection{Data Acquisition}

The signals from the seismometer sites are monitored for changes in signal amplitude that are expected from earthquakes. The seismic network is subdivided into spatial groupings of stations that are monitored for nearly simultaneous amplitude changes, resulting in triggering a permanent recording of the events. The groupings and associated weighting schemes are designed to allow very small seismic events to be recorded and to minimize false triggers. Events are classified as local (south-central Washington near the Hanford Site), regional (Western U.S. and Canada), and teleseisms (from farther distances around the world). Local and regional events are usually earthquakes, but quarry and mining explosions are also recorded. Quarry and mining explosions can usually be identified from wave characteristics, 
Table 2.2. Seismic Stations in the Eastern Washington Regional Network

\begin{tabular}{|c|c|c|c|c|}
\hline Station & $\begin{array}{c}\text { Latitude } \\
\text { Deg. Min. N. }\end{array}$ & $\begin{array}{c}\text { Longitude } \\
\text { Deg. Min. W. }\end{array}$ & Elevation (m) & Station Name \\
\hline$\overline{\text { BRV }}$ & $=46 \mathrm{~N} 29.12$ & 1119W59.47 & 920 & Black Rock Valley \\
\hline BVW & $46 \mathrm{~N} 48.66$ & 119W52.99 & 670 & Beverly \\
\hline CBS & $47 \mathrm{~N} 48.26$ & $120 \mathrm{~W} 02.50$ & 1,067 & Chelan Butte, South \\
\hline CRF & $46 \mathrm{~N} 49.50$ & $119 \mathrm{~W} 23.22$ & 189 & Corfu \\
\hline DPW & $47 \mathrm{~N} 52.25$ & $118 \mathrm{~W} 12.17$ & 892 & Davenport \\
\hline DY2 & $47 N 59.11$ & $119 \mathrm{~W} 46.28$ & 890 & Dyer Hill Two \\
\hline ELL & $46 \mathrm{~N} 54.58$ & 120W33.98 & 789 & Ellensburg \\
\hline EPH & $47 \mathrm{~N} 21.38$ & 119W35.76 & 661 & Ephrata \\
\hline ET3 & $46 \mathrm{~N} 34.64$ & $118 \mathrm{~W} 56.25$ & 286 & Eltopia Three \\
\hline ETW & $47 \mathrm{~N} 36.26$ & $120 \mathrm{~W} 19.94$ & 1,477 & Entiat \\
\hline *FHE & $46 \mathrm{~N} 57.11$ & $119 \mathrm{~W} 29.82$ & 455 & Frenchman Hills East \\
\hline$* \mathrm{GBL}$ & $46 \mathrm{~N} 35.92$ & $119 \mathrm{~W} 27.58$ & 330 & Gable Mountain \\
\hline LNO & $45 \mathrm{~N} 52.31$ & $118 \mathrm{~W} 17.11$ & 771 & Lincton Mountain, Oregon \\
\hline LOC & $46 \mathrm{~N} 43.02$ & $119 \mathrm{~W} 25.85$ & 210 & Locke Island \\
\hline MDW & $46 \mathrm{~N} 36.79$ & $119 \mathrm{~W} 45.66$ & 330 & Midway \\
\hline MJ2 & $46 \mathrm{~N} 33.45$ & $119 \mathrm{~W} 21.54$ & 146 & May Junction Two \\
\hline MOX & $46 \mathrm{~N} 34.64$ & 120W17.89 & 501 & Moxee City \\
\hline NAC & $46 \mathrm{~N} 43.99$ & $120 \mathrm{~W} 49.42$ & 728 & Naches \\
\hline NEL & $48 \mathrm{~N} 04.21$ & 120W20.41 & 1,500 & Nelson Butte \\
\hline OD2 & $47 \mathrm{~N} 23.26$ & $118 \mathrm{~W} 42.58$ & 553 & Odessa Two \\
\hline OT3 & $46 \mathrm{~N} 40.14$ & $119 \mathrm{~W} 13.98$ & 322 & Othello Three \\
\hline PAT & $45 \mathrm{~N} 52.92$ & $119 \mathrm{~W} 45.14$ & 262 & Paterson \\
\hline PRO & $46 \mathrm{~N} 12.73$ & $119 \mathrm{~W} 41.15$ & 550 & Prosser \\
\hline RSW & $46 \mathrm{~N} 23.67$ & 119W35.48 & 1,045 & Rattlesnake Mountain \\
\hline SAW & $47 \mathrm{~N} 42.10$ & $119 \mathrm{~W} 24.03$ & 701 & St. Andrews \\
\hline TBM & $47 \mathrm{~N} 10.20$ & 120W35.88 & 1,006 & Table Mountain \\
\hline TRW & $46 \mathrm{~N} 17.32$ & 120W32.31 & 723 & Toppenish Ridge \\
\hline TWW & $47 \mathrm{~N} 08.29$ & 120W52.10 & 1,027 & Teanaway \\
\hline VT2 & 46N58.04 & 119W58.95 & 1,270 & Vantage Two \\
\hline WA2 & $46 \mathrm{~N} 45.32$ & $119 \mathrm{~W} 33.94$ & 244 & Wahluke Slope Two \\
\hline WAT & $47 \mathrm{~N} 41.92$ & 119W57.24 & 821 & Waterville \\
\hline WIW & $46 \mathrm{~N} 25.76$ & $119 \mathrm{~W} 17.26$ & 128 & Wooded Island \\
\hline WRD & $46 \mathrm{~N} 58.20$ & 119W08.69 & 375 & Warden \\
\hline YA2 & $46 \mathrm{~N} 31.60$ & $120 \mathrm{~W} 31.80$ & 652 & Yakima Two \\
\hline YPT & $46 \mathrm{~N} 02.93$ & 118W57.73 & 325 & Yellepit \\
\hline
\end{tabular}




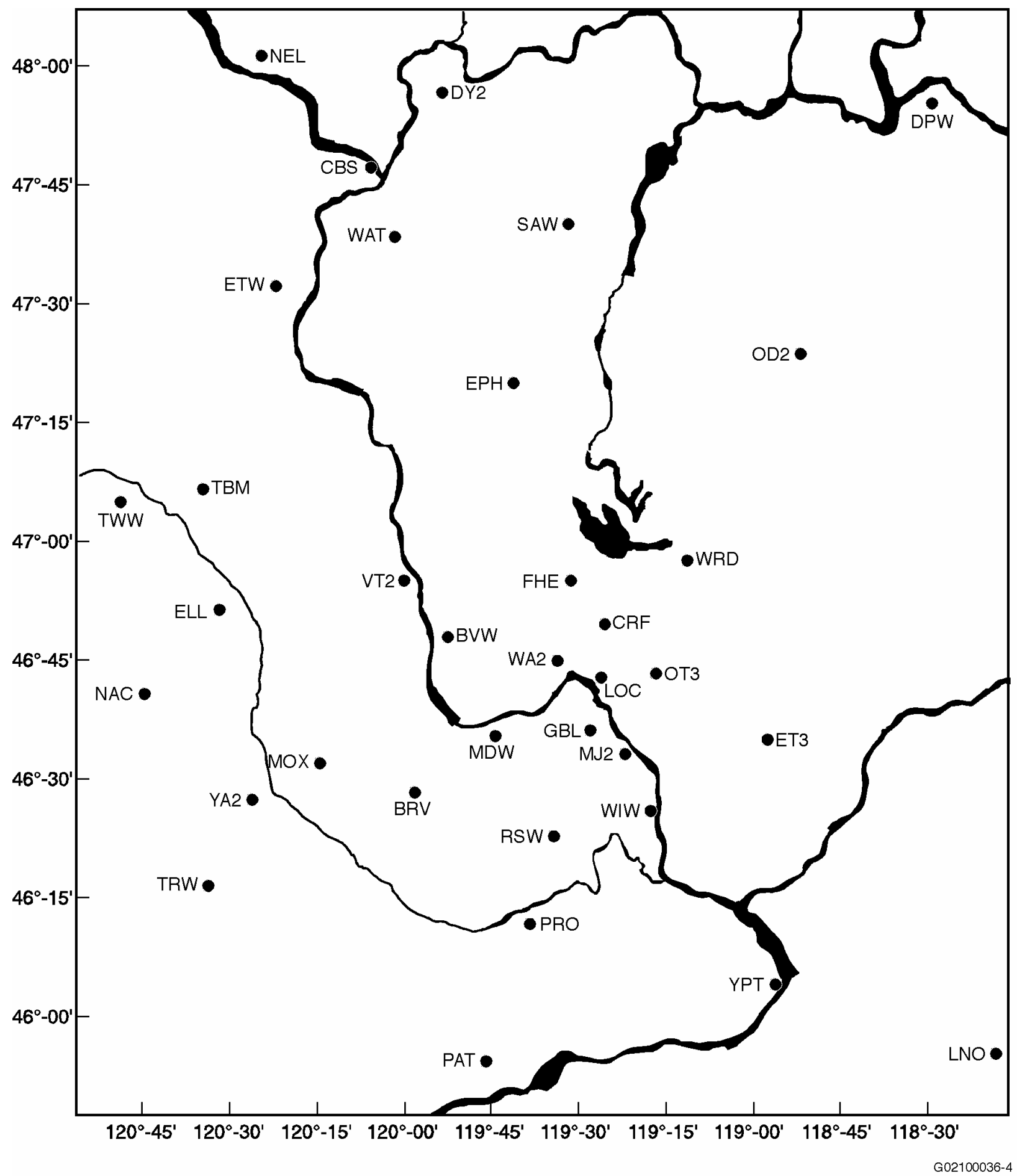

Figure 2.2. Locations of Seismograph Stations in the Eastern Washington Regional Network (see Table 2.2 for location descriptions). 
time of day, and through confirmation with local government agencies and industries. Frequently, military exercises at the U.S. Army's Yakima Training Center produce a series of acoustic shocks that unavoidably trigger the recording system. Sonic booms and thunder also produce acoustic signals that trigger the recording system.

A PC-based system (Earthworm system) adapted from a USGS program and the UW system was implemented at Hanford during FY 1999. One system has been in continuous operation since January 6, 1999. A second, backup PC system was installed in mid-March 1999, and both systems have been running in parallel since that time. The hardware and software have been periodically upgraded. Data from triggers are collected on a SUN ${ }^{\text {TM }}$ (registered trademark of Sun Microsystems, Santa Clara, California) workstation that is used to determine earthquake locations and magnitudes (Section 3). Although the two systems are practically identical, there is enough granularity (signal-to-noise) in the trigger timing that they sometimes record exclusive events. In nearly all cases, these exclusive triggers are "false" triggers, not earthquakes or quarry blasts (i.e., from acoustic sources). The remainders are from barely detectable, small signals from regional and teleseismic earthquakes.

The types and numbers of triggers recorded in FY 2003 by the seismic acquisition system are summarized in Table 2.3.

Table 2.3. Acquisition System Recorded Triggers

\begin{tabular}{|c|c|c|c|c|c|c|}
\hline Event Type & $\begin{array}{c}\text { First } \\
\text { Quarter }\end{array}$ & $\begin{array}{l}\text { Second } \\
\text { Quarter } \\
\end{array}$ & $\begin{array}{c}\text { Third } \\
\text { Quarter }\end{array}$ & $\begin{array}{l}\text { Fourth } \\
\text { Quarter } \\
\end{array}$ & Total & Description \\
\hline $\begin{array}{l}\text { South-Central } \\
\text { Washington }\end{array}$ & 46 & 40 & 49 & - & 135 & $\begin{array}{l}\text { Seismic events in south-central } \\
\text { Washington and north-central Oregon } \\
\text { that triggered the HSN. }\end{array}$ \\
\hline Regional & 44 & 47 & 31 & - & 122 & $\begin{array}{l}\text { Seismic events in the Western United } \\
\text { States and Canada. }\end{array}$ \\
\hline Teleseism & 81 & 54 & 61 & - & 196 & $\begin{array}{l}\text { Seismic events at farther distances from } \\
\text { around the world. }\end{array}$ \\
\hline $\begin{array}{l}\text { Total Earthquake } \\
\text { Events }\end{array}$ & 171 & 141 & 141 & - & 453 & Total number of earthquake triggers. \\
\hline $\begin{array}{l}\text { Total Triggers on } \\
\text { Primary System }\end{array}$ & 342 & 271 & 356 & - & 969 & $\begin{array}{l}\text { Total number of triggers examined. } \\
\text { Includes all sources of triggers. }\end{array}$ \\
\hline Local Explosions & 2 & 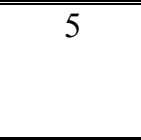 & 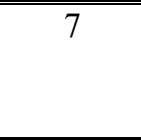 & - & 14 & $\begin{array}{l}\text { Quarry blasts, typically, within the } \\
46-47 \text { degrees north latitude and } \\
119-120 \text { degrees west longitude. }\end{array}$ \\
\hline Local Earthquakes & 29 & 20 & 34 & - & 83 & $\begin{array}{l}\text { Seismic events within the } 46-47 \text { degrees } \\
\text { north latitude and } 119-120 \text { degrees west } \\
\text { longitude. }\end{array}$ \\
\hline
\end{tabular}




\subsection{Strong Motion Accelerometer Sites}

\subsubsection{Location}

The Hanford SMA network consists of five free-field SMA sites (see Figure 2.1) (Table 2.4). There is one free-field SMA located in each of the 200 Separations Areas, one adjacent to the K Basins in the 100-K Area, one adjacent to the 400 Area where the Fast Flux Test Reactor is located, and one at the south end of the 300 Area. With the termination of the Fast Flux Test Reactor and draining of the liquid sodium coolant taking place now, we are making plans to terminate this site and move the instrument to a new location.

The instrumentation locations were chosen based on two criteria (Moore and Reidel 1996): 1) instruments should be located in areas having the highest densities of people and 2) instruments should be located in areas having hazardous facilities. Some of the highest concentrations of employees at Hanford are 200 East and West Areas, 100-K Area, the Fast Flux Test Facility (400 Area), and the 300 Areas. The 200 Areas are where high-level radioactive waste from past processing of fuel rods is stored in singleshell and double-shell tanks. In addition, the Canister Storage Facility that holds encapsulated spent fuel rods is in 200 East Area and the new vitrification plant is being constructed in 200 East Area. The 100-K Area contains the K Basins where spent fuel rods from the $\mathrm{N}$ Reactor are stored prior to encapsulation. The Cold Vacuum Drying Facility, located in the 100-K Area, is used to encapsulate spent fuel rods from the K Basins prior to shipment to the Canister Storage Building in 200 East Area.

Table 2.4. Free-Field Strong Motion Accelerometer Sites

\begin{tabular}{|c|c|c|c|}
\hline Site & Site ID & Location & $\begin{array}{c}\text { Latitude } \\
\text { Longitude } \\
\text { Elevation }\end{array}$ \\
\hline $100-$ K Area & $\mathrm{H} 1 \mathrm{~K}$ & South of K Basins outside 100 Area fence lines. & $\begin{array}{l}46^{\circ} 38.51^{\prime}, \\
119^{\circ} 35.53^{\prime} \\
152 \mathrm{~m}\end{array}$ \\
\hline 200 East Area & $\mathrm{H} 2 \mathrm{E}$ & $\begin{array}{l}\text { East of B Plant; north of } 7^{\text {th }} \text { Street and east of } \\
\text { Baltimore Avenue. }\end{array}$ & $\begin{array}{l}46^{\circ} 33.58^{\prime} \\
119^{\circ} 32.00^{\prime} \\
210 \mathrm{~m}\end{array}$ \\
\hline 200 West Area & $\mathrm{H} 2 \mathrm{~W}$ & $\begin{array}{l}\text { Northeast of Plutonium Finishing Plant (PFP); north of } \\
19^{\text {th }} \text { street and east of Camden Avenue. }\end{array}$ & \begin{tabular}{|l|}
$46^{\circ} 33.23^{\prime}$ \\
$119^{\circ} 37.51^{\prime}$ \\
$206 \mathrm{~m}$ \\
\end{tabular} \\
\hline 300 Area & $\mathrm{H} 3 \mathrm{~A}$ & $\begin{array}{l}\text { South end of } 300 \text { Area inside fence lines. (NE } 1 / 4, \mathrm{SW} \\
1 / 4 \text {, Sec. } 11, \mathrm{~T} 10 \mathrm{~N}, \mathrm{R} 28 \mathrm{E}) \text {. }\end{array}$ & $\begin{array}{l}46^{\circ} 21.83^{\prime} \\
119^{\circ} 16.55^{\prime} \\
119 \mathrm{~m}\end{array}$ \\
\hline 400 Area & $\mathrm{H} 4 \mathrm{~A}$ & $\begin{array}{l}500 \text { feet from fence line on east side of facility and } \\
\text { north of parking area). }\end{array}$ & $\begin{array}{l}46^{\circ} 26.13^{\prime} \\
119^{\circ} 21.30^{\prime} \\
171 \mathrm{~m}\end{array}$ \\
\hline
\end{tabular}




\subsubsection{Site Design}

All free-field SMA sites consist of a four-panel solar array and two 30-gallon galvanized drums. Each panel has a maximum 42-watt output. The two 30-gallon drums are set in the ground such that the base of the drum is about $1 \mathrm{~m}$ below the surface. One drum houses only the SMA; the other drum, which is connected via a sealed conduit to the SMA drum, contains the batteries. Communication is through a Cellular Digital Packet Data (CDPD) system, which provides a continuous radio data-link with the AT\&T internet service. This CDPD system along with the solar regulator is housed in a small enclosure mounted at the rear of the solar array. The enclosure serves as a junction box for all cabling between in the drums and outside the drums through conduit. The antenna for the CDPD is mounted on top of the enclosure. The enclosure permits quick access to check battery conditions and a connection directly to the RS-232 port of the SMA without removing the drum lids. The CDPD system is scheduled to be terminated by AT\&T and replaced with a new system in January 2004.

The SMA instruments are three-component units consisting of one vertical, one north-south horizontal, and one east-west horizontal data channel. The instruments in use are the ETNA ${ }^{\mathrm{TM}}$ system (registered trademark of Kinemetrics, Inc., Pasadena, California). Instrument specifications are summarized in Table 2.5. In addition to the three-component SMAs, each ETNA SMA unit contains a computer, Global Positioning System (GPS) receiver (Figure 2.3). These systems are housed in a watertight box.

The CDPD system provides the Internet address connection to access the system. Stations can be monitored from any computer, and data can be downloaded to a dedicated computer in the seismic monitoring laboratory. The data can also be downloaded directly at each site via a built in cable connection at the enclosure in case of communication failure.

Table 2.5. Instrument Parameters for the Kinemetrics ETNA ${ }^{\text {TM }}$ System in the Hanford SMA Network

\begin{tabular}{|c|c|}
\hline Parameter & Value or Range \\
\hline \multicolumn{2}{|l|}{ Sensor } \\
\hline Type & Tri-axial Force Balance Accelerometer orthogonally oriented with internal standard \\
\hline Full-Scale & $\pm 2 \mathrm{~g}^{(\mathrm{a})}$ \\
\hline Frequency Range & $0-50 \mathrm{~Hz}$ \\
\hline Damping & Approximately $70 \%$ critical $^{(\mathrm{a})}$ \\
\hline \multicolumn{2}{|l|}{ Data Acquisition } \\
\hline Number of Channels & 3 \\
\hline Sample Rate & 18-bit resolution@200 samples/second \\
\hline Digital Output & Real-time, RS-232 Output Stream \\
\hline \multicolumn{2}{|l|}{ Seismic Trigger } \\
\hline Filter & $0.1-12.5 \mathrm{~Hz}$ \\
\hline Trigger level & $0.10 \%-0.20 \% \mathrm{~g}^{(\mathrm{b})}$ \\
\hline Alarm (call-out) Threshold & Not activated \\
\hline Pre-event Memory & $10 \mathrm{sec}$ \\
\hline Post-event Time & $40 \mathrm{sec}$ \\
\hline \multicolumn{2}{|c|}{ (a) Setting is dependent on instrument calibration. } \\
\hline
\end{tabular}




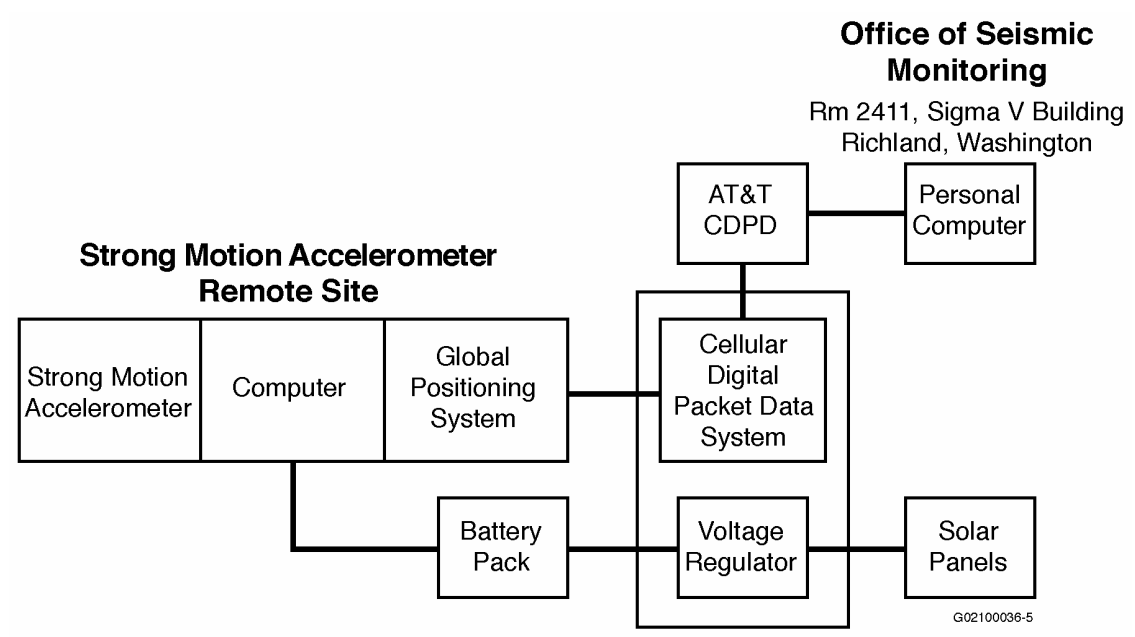

Figure 2.3. Schematic Diagram of a Strong Motion Accelerometer Installation

The SMAs have an internal GPS receiver used principally to link it to the National Bureau of Standards timing system. ${ }^{\text {(a) }}$ The GPS is internally activated approximately every 4 hours and checks the "location of the instrument" and the time. Any differences between the internal clock and the GPS time are recorded and saved by the SMA. Any corrections to the internal timing are made automatically. Typically, the greatest correction recorded is approximately 4 milliseconds.

\subsubsection{Strong Motion Accelerometer Operations Center}

The combined operations, data recording, data interpretation, and maintenance facility is located in the Sigma V building and is operated by the PNNL Seismic Monitoring Team.

\subsubsection{Strong Motion Operational Characteristics}

The signals from the three-accelerometer channels at each site are digitized with a 24-bit digitizer and temporarily stored in a memory buffer. The sampling rate of the digitizer is set to $200 \mathrm{samples} / \mathrm{second}$. The three channels are monitored for signals that equal or exceed a programmable trigger threshold. When one accelerometer channel is triggered, the other channels automatically record. The nominal threshold used is $0.05 \%$ of the full-scale range of $2.0 \mathrm{~g}$ ( $\mathrm{g}$ is the acceleration of gravity, $9.8 \mathrm{~m} / \mathrm{s}^{2}$ or $32 \mathrm{ft} / \mathrm{s}^{2}$ ) or $0.001 \mathrm{~g}$. Threshold trigger levels are being adjusted to trigger infrequently on the noise sources (e.g., vehicles, sonic booms) near each site. This will provide ground motion data for smaller, non-damaging earthquakes that can be useful in estimating the ground motion expected from larger earthquakes, and to confirm correct operation of the instruments by analyzing the smaller-amplitude triggers. The recorders store information for 10 seconds before the trigger threshold is exceeded and for 40 seconds after the trigger ceases to be exceeded.

(a) The GPS antenna is mounted on the enclosure at the rear of the solar array. 


\subsection{Earthquake Catalog Description}

Seismic Monitoring staff uses an interactive program XPED developed at the University of Washington to determine earthquake locations and magnitudes. This program operates on the sections of time saved in files by the trigger algorithm of the Earthworm system. It provides the user with the ability to measure the arrival times and durations of seismic waves from earthquakes and determine the locations and magnitudes of the events. Locations of teleseismic and regional earthquakes are interpreted and saved for operational and quality review and documentation, and are not reported here. Local earthquakes near the Hanford Site $\left(46^{\circ}-47^{\circ} \mathrm{N}, 119^{\circ}-120^{\circ} \mathrm{W}\right)$ are reported in this report (Table 3.2). Other earthquakes in southeast Washington are kept on file.

\subsection{Coda Length Magnitude}

Coda-length magnitude $\left(\mathrm{M}_{\mathrm{c}}\right)$, an estimate of local magnitude $\left(\mathrm{M}_{\mathrm{L}}\right)$ (Richter 1958), is calculated using the coda-length/magnitude relationship determined for Washington State by Crosson (1972).

This relationship is:

$$
\mathrm{M}_{\mathrm{c}}=2.82 \log (\mathrm{D})-2.46
$$

where $\mathrm{D}$ is the duration of the observed signal.

Coda-length magnitude

\subsection{Velocity Model}

The program XPED uses the velocities and layer depths given in Table 3.1. This model does not include a surficial layer for the Hanford or Ringold sediments because most stations are located on basalt. Time corrections, which account for elevation, or local differences in the velocity model (i.e., stations on sedimentary layers), are determined empirically from sets of accurately-located earthquakes and explosions in the region.

Table 3.1. $\quad$ Seismic Velocities for Columbia Basin Stratigraphy (from Rohay et al. 1985)

\begin{tabular}{||c|l|c||}
\hline $\begin{array}{c}\text { Depth to Top of Velocity } \\
\text { Layer }(\mathbf{k m})\end{array}$ & \multicolumn{1}{|c||}{ Stratigraphy } & $\begin{array}{c}\text { Velocity } \\
\mathbf{( k m} / \mathbf{s e c})\end{array}$ \\
\hline \hline 0.0 & $\begin{array}{l}\text { Saddle Mountains and Wanapum Basalts and intercalated } \\
\text { Ellensburg Formation }\end{array}$ & 3.7 \\
\hline 0.4 & Grande Ronde Basalt and pre-basalt sediments & 5.2 \\
\hline 8.5 & Crystalline Basement, Layer 1 & 6.1 \\
\hline 13.0 & Crystalline Basement, Layer 2 & 6.4 \\
\hline 23.0 & Sub-basement & 7.1 \\
\hline 38.0 & Mantle & 7.9 \\
\hline
\end{tabular}


Table 3.2. Local Seismic Data, October 1, 2002 to June 31, 2003

\begin{tabular}{|c|c|c|c|c|c|c|c|c|c|c|c|c|c|}
\hline Event ID & Type & Date & Time & Latitutde & Longitude & Depth & Mag & NS/NP & Gap & Dmin & RMS & $\mathbf{Q}$ & Location \\
\hline 02100619012 & & $02 / 10 / 06$ & 19:01:46.23 & 46N06.92 & 119W26.70 & 9.16 & 0.7 & $12 / 15$ & 193 & 20 & 0.11 & $\overline{\mathrm{AD}}$ & $22.1 \mathrm{~km} \mathrm{SSW}$ of Richland \\
\hline 02100619322 & & $02 / 10 / 06$ & 19:32:42.27 & $46 \mathrm{~N} 07.43$ & 119W26.63 & 7.55 & 0.6 & $7 / 11$ & 316 & 19 & 0.10 & $\mathrm{BD}$ & $21.3 \mathrm{~km} \mathrm{SSW}$ of Richland \\
\hline 02100803071 & & $02 / 10 / 08$ & 03:07:41.10 & $46 \mathrm{~N} 18.67$ & $119 \mathrm{~W} 32.30$ & 7.98 & 0.7 & $14 / 14$ & 124 & 7 & 0.09 & $\mathrm{AB}$ & $19.3 \mathrm{~km} \mathrm{~W}$ of Richland \\
\hline 02101205244 & & $02 / 10 / 12$ & 05:25:06.45 & $46 \mathrm{~N} 50.60$ & $119 \mathrm{~W} 44.22$ & 3.49 & 1.5 & $20 / 21$ & 70 & 11 & 0.13 & $\mathrm{AC}$ & $22.7 \mathrm{~km}$ SE of Vantage \\
\hline 02102210321 & & $02 / 10 / 22$ & 10:32:33.39 & $46 \mathrm{~N} 50.71$ & 119W47.35 & 2.42 & 2.7 & $39 / 40$ & 43 & 8 & 0.17 & $\mathrm{BB}$ & $19.4 \mathrm{~km}$ SE of Vantage \\
\hline 02102806211 & & $02 / 10 / 28$ & $06: 21: 41.82$ & $46 \mathrm{~N} 23.02$ & $119 \mathrm{~W} 35.24$ & 18.17 & 0.4 & $14 / 14$ & 196 & 1 & 0.07 & $\mathrm{AD}$ & $18.5 \mathrm{~km} \mathrm{WSW} \mathrm{of} 400$ Area \\
\hline 02103013381 & & $02 / 10 / 30$ & $13: 38: 36.14$ & $46 \mathrm{~N} 36.49$ & 119W46.90 & 8.45 & 0.0 & $14 / 16$ & 111 & 1 & 0.09 & $\mathrm{AB}$ & $12.4 \mathrm{~km} \mathrm{WNW}$ of $200 \mathrm{West}$ \\
\hline 02103101295 & & $02 / 10 / 31$ & $01: 30: 16.57$ & $46 \mathrm{~N} 50.28$ & $119 \mathrm{~W} 19.78$ & 2.65 & 0.5 & $16 / 16$ & 90 & 4 & 0.07 & AA & $12.5 \mathrm{~km} \mathrm{~W}$ of Othello \\
\hline 02103120351 & & $02 / 10 / 31$ & $20: 35: 41.98$ & $46 \mathrm{~N} 43.69$ & $119 \mathrm{~W} 31.04$ & 0.02 & -0.1 & $9 / 10$ & 73 & 4 & 0.13 & AA & $11.4 \mathrm{~km}$ NNE of $100-\mathrm{K}$ Area \\
\hline 02110323592 & & $02 / 11 / 03$ & $23: 59: 49.84$ & $46 \mathrm{~N} 47.34$ & $119 \mathrm{~W} 10.63$ & 14.87 & 1.3 & $30 / 41$ & 113 & 14 & 0.13 & $\mathrm{AB}$ & $4.3 \mathrm{~km} \mathrm{~S}$ of Othello \\
\hline 02110403334 & & $02 / 11 / 04$ & 03:34:02.26 & $46 \mathrm{~N} 14.69$ & 119W01.00 & 12.69 & 0.3 & $12 / 17$ & 159 & 22 & 0.17 & $\mathrm{BC}$ & $6.3 \mathrm{~km} \mathrm{E}$ of Pasco \\
\hline 02110407344 & & $02 / 11 / 04$ & 07:35:06.62 & 46N27.32 & 119W34.89 & 15.86 & -0.1 & $10 / 14$ & 92 & 6 & 0.05 & $\mathrm{AB}$ & $12.2 \mathrm{~km} \mathrm{SSW}$ of 200 East \\
\hline 02110413204 & & $02 / 11 / 04$ & 13:21:08.05 & $46 \mathrm{~N} 40.55$ & 119W34.98 & 13.20 & 0.4 & $13 / 16$ & 65 & 8 & 0.08 & AA & $3.9 \mathrm{~km}$ NNE of $100-\mathrm{K}$ Area \\
\hline 02110504052 & & $02 / 11 / 05$ & $04: 05: 53.58$ & $46 \mathrm{~N} 27.17$ & $119 \mathrm{~W} 36.81$ & 15.00 & 0.6 & $13 / 15$ & 111 & 3 & 0.06 & $\mathrm{AB}$ & $11.8 \mathrm{~km} \mathrm{~S}$ of $200 \mathrm{West}$ \\
\hline 02110612274 & & $02 / 11 / 06$ & 12:28:05.14 & $46 \mathrm{~N} 33.04$ & $119 \mathrm{~W} 13.83$ & 16.23 & 0.3 & $13 / 18$ & 150 & 9 & 0.08 & $\mathrm{AC}$ & $16.2 \mathrm{~km} \mathrm{NE}$ of 400 Area \\
\hline 02110800555 & & $02 / 11 / 08$ & $00: 56: 19.55$ & $46 \mathrm{~N} 40.73$ & $119 \mathrm{~W} 38.26$ & 15.84 & -0.2 & $16 / 20$ & 61 & 7 & 0.11 & AA & $5.1 \mathrm{~km} \mathrm{NW}$ of $100-\mathrm{K}$ Area \\
\hline 02110920575 & & $02 / 11 / 09$ & $20: 58: 11.00$ & $46 \mathrm{~N} 33.75$ & $119 \mathrm{~W} 35.26$ & 24.08 & 0.3 & $14 / 18$ & 65 & 5 & 0.07 & AA & $3.9 \mathrm{~km} \mathrm{E}$ of $200 \mathrm{West}$ \\
\hline 02111001232 & & $02 / 11 / 10$ & $01: 23: 44.41$ & $46 \mathrm{~N} 50.06$ & $119 \mathrm{~W} 33.54$ & 14.68 & 0.2 & $11 / 14$ & 130 & 8 & 0.11 & $\mathrm{AB}$ & $21.6 \mathrm{~km} \mathrm{~N}$ of $100-\mathrm{K}$ Area \\
\hline 02111023574 & & $02 / 11 / 10$ & 23:58:05.92 & 46N51.91 & $119 \mathrm{~W} 25.36$ & 18.98 & 0.4 & $14 / 16$ & 107 & 5 & 0.14 & $\mathrm{AB}$ & $20.0 \mathrm{~km}$ WNW of Othello \\
\hline 02111609344 & & $02 / 11 / 16$ & 09:35:06.62 & $46 \mathrm{~N} 50.24$ & 119W33.07 & 15.94 & 1.4 & $32 / 36$ & 31 & 9 & 0.13 & AA & $22.0 \mathrm{~km} \mathrm{~N}$ of $100-\mathrm{K}$ Area \\
\hline 02112004435 & & $02 / 11 / 20$ & 04:44:22.18 & $46 \mathrm{~N} 36.66$ & $119 \mathrm{~W} 46.10$ & 16.08 & 0.1 & $6 / 11$ & 269 & 0 & 0.06 & $\mathrm{AD}$ & $11.6 \mathrm{~km} \mathrm{WNW}$ of $200 \mathrm{West}$ \\
\hline 02112004482 & & $02 / 11 / 20$ & 04:48:43.71 & $46 \mathrm{~N} 36.91$ & $119 \mathrm{~W} 46.32$ & 17.06 & 0.0 & $7 / 10$ & 180 & 0 & 0.06 & $\mathrm{AC}$ & $12.1 \mathrm{~km} \mathrm{WNW}$ of $200 \mathrm{West}$ \\
\hline 02120205272 & & $02 / 12 / 02$ & 05:27:49.61 & $46 \mathrm{~N} 34.67$ & $119 \mathrm{~W} 42.44$ & 14.37 & -0.2 & $3 / 05$ & 127 & 5 & 0.04 & $\mathrm{AD}$ & $5.8 \mathrm{~km} \mathrm{WNW}$ of $200 \mathrm{West}$ \\
\hline 02120622321 & $\mathrm{X}$ & $02 / 12 / 06$ & $22: 32: 38.39$ & $46 \mathrm{~N} 10.11$ & $119 \mathrm{~W} 28.62$ & 0.63 & & $9 / 09$ & 260 & 14 & 0.11 & $\mathrm{BD}$ & $19.2 \mathrm{~km} \mathrm{SW}$ of Richland \\
\hline 02121417035 & & $02 / 12 / 14$ & 17:04:20.95 & $46 \mathrm{~N} 20.29$ & 119W32.89 & 16.58 & 0.6 & $15 / 16$ & 99 & 6 & 0.07 & $\mathrm{AB}$ & $18.2 \mathrm{~km} \mathrm{SW}$ of 400 Area \\
\hline 02122206575 & & $02 / 12 / 22$ & 06:58:16.19 & $46 \mathrm{~N} 22.93$ & 119W02.73 & 4.85 & 0.3 & $6 / 09$ & 149 & 19 & 0.17 & $\mathrm{BC}$ & $16.8 \mathrm{~km}$ NNE of Pasco \\
\hline 02122211403 & & $02 / 12 / 22$ & $11: 40: 50.99$ & $46 \mathrm{~N} 19.32$ & $119 \mathrm{~W} 30.02$ & 4.09 & 0.6 & $8 / 10$ & 110 & 5 & 0.76 & DB & 16.6 km WNW of Richland \\
\hline 02122211412 & & $02 / 12 / 22$ & 11:41:28.31 & $46 \mathrm{~N} 16.17$ & 119W28.04 & 10.95 & 0.6 & $10 / 16$ & 287 & 3 & 0.14 & $\mathrm{AD}$ & $13.6 \mathrm{~km} \mathrm{~W}$ of Richland \\
\hline 02122211542 & & $02 / 12 / 22$ & $11: 54: 39.64$ & $46 \mathrm{~N} 15.72$ & 119W28.27 & 10.60 & 0.3 & $8 / 13$ & 289 & 4 & 0.04 & $\mathrm{AD}$ & $14.0 \mathrm{~km} \mathrm{~W}$ of Richland \\
\hline 02122911410 & & $02 / 12 / 29$ & 11:41:22.66 & $46 \mathrm{~N} 43.48$ & 119W04.92 & 10.83 & 1.3 & $8 / 19$ & 124 & 13 & 0.08 & $\mathrm{AB}$ & $13.1 \mathrm{~km}$ SSE of Othello \\
\hline 02123022330 & $\mathrm{X}$ & $02 / 12 / 30$ & $22: 33: 31.16$ & $46 \mathrm{~N} 16.10$ & $119 \mathrm{~W} 23.66$ & 0.02 & & $13 / 13$ & 229 & 4 & 0.10 & $\mathrm{AD}$ & $8.1 \mathrm{~km} \mathrm{WSW}$ of Richland \\
\hline 03011421583 & $\mathrm{X}$ & $03 / 01 / 14$ & $21: 58: 59.57$ & $46 \mathrm{~N} 15.82$ & $119 \mathrm{~W} 23.58$ & 0.07 & & $13 / 13$ & 232 & 5 & 0.13 & $\mathrm{AD}$ & $8.1 \mathrm{~km}$ WSW of Richland \\
\hline 03012400230 & $\mathrm{P}$ & $03 / 01 / 24$ & 00:23:29.86 & $46 \mathrm{~N} 15.94$ & 119W23.48 & 3.12 & & $12 / 12$ & 129 & 5 & 0.09 & $\mathrm{AB}$ & $7.9 \mathrm{~km}$ WSW of Richland \\
\hline 03012611344 & & $03 / 01 / 26$ & 11:35:09.10 & $46 \mathrm{~N} 29.40$ & 119W20.58 & 0.35 & 1.0 & $8 / 08$ & 124 & 7 & 0.08 & $\mathrm{AB}$ & $6.2 \mathrm{~km} \mathrm{~N}$ of 400 Area \\
\hline
\end{tabular}


Table 3.2. (Contd.)

\begin{tabular}{|c|c|c|c|c|c|c|c|c|c|c|c|c|c|}
\hline Event ID & Type & Date & Time & Latitutde & Longitude & Depth & Mag & MS/NP & Gap & Dmin & RMS & $\mathbf{Q}$ & Location \\
\hline 03012821092 & $\mathrm{X}$ & $03 / 01 / 28$ & $21: 09: 50.34$ & 46N08.73 & $119 \mathrm{~W} 11.82$ & 0.05 & & $15 / 15$ & 188 & 21 & 0.18 & $\mathrm{BD}$ & $8.6 \mathrm{~km} \mathrm{SW}$ of Kennewick \\
\hline 03020416331 & & $03 / 02 / 04$ & $16: 33: 39.63$ & $46 \mathrm{~N} 27.62$ & $119 \mathrm{~W} 01.21$ & 15.76 & 1.7 & $21 / 21$ & 113 & 14 & 0.14 & $\mathrm{AB}$ & $22.9 \mathrm{~km}$ ENE of 300 Area \\
\hline 03021202012 & & $03 / 02 / 12$ & 02:01:47.14 & $46 \mathrm{~N} 36.18$ & $119 \mathrm{~W} 45.14$ & 16.56 & 0.8 & $15 / 18$ & 165 & 1 & 0.07 & $\mathrm{AC}$ & $10.1 \mathrm{~km} \mathrm{WNW}$ of $200 \mathrm{West}$ \\
\hline 03021222082 & $\mathrm{X}$ & $03 / 02 / 12$ & $22: 08: 42.73$ & $46 \mathrm{~N} 08.74$ & $119 \mathrm{~W} 11.13$ & 0.84 & & $14 / 14$ & 158 & 20 & 0.13 & $\mathrm{BC}$ & $8.0 \mathrm{~km} \mathrm{SW}$ of Kennewick \\
\hline 03021417463 & & $03 / 02 / 14$ & $17: 46: 54.14$ & $46 \mathrm{~N} 36.21$ & 119W51.58 & 6.54 & 0.3 & $8 / 09$ & 217 & 7 & 0.06 & $\mathrm{AD}$ & $17.7 \mathrm{~km} \mathrm{WNW}$ of $200 \mathrm{West}$ \\
\hline 03021621242 & & $03 / 02 / 16$ & $21: 24: 44.95$ & $46 \mathrm{~N} 33.92$ & 119W53.34 & 8.15 & 0.1 & $3 / 06$ & 310 & 11 & 0.09 & $\mathrm{BD}$ & $19.3 \mathrm{~km} \mathrm{~W}$ of $200 \mathrm{West}$ \\
\hline 03021807232 & & $03 / 02 / 18$ & $07: 23: 42.64$ & $46 \mathrm{~N} 27.18$ & 119W37.09 & 17.21 & -0.1 & $8 / 11$ & 128 & 3 & 0.07 & $\mathrm{AB}$ & $11.8 \mathrm{~km} \mathrm{~S}$ of $200 \mathrm{West}$ \\
\hline 03021822404 & $\mathrm{P}$ & $03 / 02 / 18$ & $22: 41: 10.59$ & $46 \mathrm{~N} 59.69$ & $119 \mathrm{~W} 12.89$ & 0.84 & & $8 / 08$ & 153 & 6 & 0.07 & $\mathrm{AC}$ & 15.6 km SSE of Moses Lake \\
\hline 03030910315 & & $03 / 03 / 09$ & $10: 32: 20.29$ & $46 \mathrm{~N} 44.93$ & 119W22.18 & 3.15 & 0.7 & $13 / 14$ & 95 & 5 & 0.06 & $\mathrm{AB}$ & $17.8 \mathrm{~km} \mathrm{WSW}$ of Othello \\
\hline 03031305552 & & $03 / 03 / 13$ & $05: 55: 39.58$ & $46 \mathrm{~N} 57.15$ & 119W07.57 & 3.88 & 0.5 & $6 / 08$ & 161 & 2 & 0.14 & $\mathrm{BC}$ & $14.3 \mathrm{~km} \mathrm{NNE}$ of Othello \\
\hline 03031411402 & & $03 / 03 / 14$ & $11: 40: 45.59$ & $46 \mathrm{~N} 24.24$ & $119 \mathrm{~W} 23.15$ & 16.58 & 0.6 & $16 / 19$ & 129 & 2 & 0.12 & $\mathrm{AB}$ & $4.1 \mathrm{~km} \mathrm{SSW}$ of 400 Area \\
\hline 03031801175 & & $03 / 03 / 18$ & 01:18:22.69 & $46 \mathrm{~N} 50.82$ & $119 \mathrm{~W} 44.10$ & 2.36 & 1.8 & $26 / 28$ & 66 & 11 & 0.11 & $\mathrm{AC}$ & $22.6 \mathrm{~km}$ ESE of Vantage \\
\hline 03031903190 & & $03 / 03 / 19$ & 03:19:14.81 & $46 \mathrm{~N} 46.24$ & 119W55.48 & 0.04 & 0.8 & $6 / 06$ & 109 & 5 & 0.09 & $\mathrm{AC}$ & $21.3 \mathrm{~km}$ SSE of Vantage \\
\hline 03031904385 & & $03 / 03 / 19$ & 04:39:20.17 & $46 \mathrm{~N} 39.59$ & $119 \mathrm{~W} 39.25$ & 16.10 & 0.0 & $12 / 15$ & 120 & 6 & 0.07 & $\mathrm{AB}$ & $4.8 \mathrm{~km} \mathrm{WNW}$ of $100-\mathrm{K}$ Area \\
\hline 03032011414 & & $03 / 03 / 20$ & $11: 42: 07.13$ & $46 \mathrm{~N} 28.92$ & $119 \mathrm{~W} 35.84$ & 12.46 & -0.1 & $7 / 10$ & 114 & 5 & 0.08 & $\mathrm{AB}$ & $9.0 \mathrm{~km} \mathrm{SSE}$ of $200 \mathrm{West}$ \\
\hline 03032115185 & & $03 / 03 / 21$ & $15: 19: 20.34$ & $46 \mathrm{~N} 29.06$ & $119 \mathrm{~W} 35.80$ & 10.66 & -0.1 & $7 / 08$ & 90 & 5 & 0.03 & $\mathrm{AB}$ & $8.8 \mathrm{~km} \mathrm{SSE}$ of $200 \mathrm{West}$ \\
\hline 03032115193 & & $03 / 03 / 21$ & $15: 19: 33.94$ & $46 \mathrm{~N} 29.28$ & $119 \mathrm{~W} 35.53$ & 9.05 & -0.3 & $7 / 09$ & 88 & 5 & 0.04 & $\mathrm{AB}$ & $8.5 \mathrm{~km} \mathrm{SSE}$ of $200 \mathrm{West}$ \\
\hline 03032323322 & & $03 / 03 / 23$ & 23:32:44.39 & $46 \mathrm{~N} 39.72$ & 119W36.75 & 0.25 & 0.0 & $6 / 06$ & 134 & 6 & 0.10 & $\mathrm{AC}$ & $2.5 \mathrm{~km} \mathrm{NNW}$ of $100-\mathrm{K}$ Area \\
\hline 03032323323 & & $03 / 03 / 23$ & $23: 32: 46.72$ & $46 \mathrm{~N} 39.81$ & $119 \mathrm{~W} 36.93$ & 0.03 & 1.9 & $18 / 19$ & 89 & 6 & 0.07 & $\mathrm{AB}$ & $2.8 \mathrm{~km} \mathrm{NNW}$ of $100-\mathrm{K}$ Area \\
\hline 03032401584 & & $03 / 03 / 24$ & $01: 57: 22.21$ & $46 \mathrm{~N} 46.75$ & 119W57.69 & 0.02 & 0.2 & $8 / 09$ & 190 & 6 & 0.18 & $\mathrm{BD}$ & $20.0 \mathrm{~km} \mathrm{~S}$ of Vantage \\
\hline 03032419435 & & $03 / 03 / 24$ & $19: 44: 19.75$ & $46 \mathrm{~N} 39.73$ & $119 \mathrm{~W} 36.79$ & 1.69 & 1.6 & $16 / 17$ & 64 & 6 & 0.05 & $\mathrm{AB}$ & $2.6 \mathrm{~km} \mathrm{NNW}$ of $100-\mathrm{K}$ Area \\
\hline 03033014200 & & $03 / 03 / 30$ & $14: 20: 28.50$ & $46 \mathrm{~N} 35.17$ & 119W20.77 & 14.09 & -0.4 & $10 / 15$ & 115 & 3 & 0.09 & $\mathrm{AB}$ & $14.8 \mathrm{~km}$ ENE of 200 East \\
\hline 03040306580 & & $03 / 04 / 03$ & $06: 58: 21.64$ & $46 \mathrm{~N} 49.35$ & $119 \mathrm{~W} 45.41$ & 0.49 & 0.3 & $11 / 14$ & 102 & 9 & 0.22 & $\mathrm{BB}$ & $22.9 \mathrm{~km} \mathrm{SE}$ of Vantage \\
\hline 03040812335 & & $03 / 04 / 08$ & $12: 34: 14.38$ & $46 \mathrm{~N} 51.49$ & $119 \mathrm{~W} 34.52$ & 2.51 & 1.4 & $24 / 26$ & 66 & 11 & 0.10 & $\mathrm{AC}$ & $24.1 \mathrm{~km} \mathrm{~N}$ of $100-\mathrm{K}$ Area \\
\hline 03042420445 & $\mathrm{P}$ & $03 / 04 / 24$ & $20: 45: 17.10$ & $46 \mathrm{~N} 13.06$ & $119 \mathrm{~W} 25.69$ & 6.02 & & $6 / 08$ & 243 & 8 & 0.15 & $\mathrm{BD}$ & $12.8 \mathrm{~km} \mathrm{SW}$ of Richland \\
\hline 03042621195 & & $03 / 04 / 26$ & 21:20:12.02 & $46 \mathrm{~N} 33.63$ & $119 \mathrm{~W} 49.26$ & 6.94 & -0.2 & $7 / 10$ & 160 & 7 & 0.15 & $\mathrm{AC}$ & $14.0 \mathrm{~km} \mathrm{~W}$ of $200 \mathrm{West}$ \\
\hline 03042701130 & & $03 / 04 / 27$ & 01:13:26.16 & $46 \mathrm{~N} 33.28$ & 119W50.97 & 5.65 & 0.9 & $13 / 14$ & 130 & 9 & 0.08 & $\mathrm{AB}$ & $16.2 \mathrm{~km} \mathrm{~W}$ of $200 \mathrm{West}$ \\
\hline 03042716233 & & $03 / 04 / 27$ & $16: 24: 00.01$ & $46 \mathrm{~N} 33.40$ & 119W50.19 & 0.02 & 0.3 & $4 / 05$ & 288 & 8 & 0.06 & $\mathrm{AD}$ & $15.2 \mathrm{~km} \mathrm{~W}$ of $200 \mathrm{West}$ \\
\hline 03043023323 & $\mathrm{P}$ & $03 / 04 / 30$ & $23: 32: 59.23$ & $46 \mathrm{~N} 14.69$ & $119 \mathrm{~W} 27.65$ & 3.81 & & $8 / 08$ & 225 & 6 & 0.06 & $\mathrm{AD}$ & $13.7 \mathrm{~km} \mathrm{WSW}$ of Richland \\
\hline 03043023370 & $\mathrm{P}$ & $03 / 04 / 30$ & $23: 37: 33.45$ & $46 \mathrm{~N} 14.90$ & $119 \mathrm{~W} 27.67$ & 3.67 & & $11 / 11$ & 223 & 5 & 0.09 & $\mathrm{AD}$ & $13.6 \mathrm{~km} \mathrm{WSW}$ of Richland \\
\hline 03050507013 & & $03 / 05 / 05$ & 07:01:55.31 & $46 \mathrm{~N} 44.68$ & $119 \mathrm{~W} 21.83$ & 0.02 & -0.6 & $6 / 08$ & 141 & 5 & 0.11 & $\mathrm{AC}$ & $17.6 \mathrm{~km} \mathrm{WSW}$ of Othello \\
\hline 03050507290 & & $03 / 05 / 05$ & $07: 29: 30.23$ & $46 \mathrm{~N} 44.84$ & $119 \mathrm{~W} 21.78$ & 3.69 & 0.5 & $16 / 19$ & 86 & 6 & 0.08 & $\mathrm{AB}$ & $17.4 \mathrm{~km} \mathrm{WSW}$ of Othello \\
\hline 03050507300 & & $03 / 05 / 05$ & 07:28:30.18 & $46 \mathrm{~N} 44.52$ & 119W22.42 & 2.47 & -0.2 & $8 / 10$ & 133 & 5 & 0.15 & $\mathrm{AB}$ & $18.4 \mathrm{~km} \mathrm{WSW}$ of Othello \\
\hline 03050602484 & & $03 / 05 / 06$ & $02: 49: 10.27$ & $46 \mathrm{~N} 16.40$ & 119W36.59 & 6.60 & 0.9 & $13 / 14$ & 142 & 8 & 0.05 & $\mathrm{AC}$ & $14.3 \mathrm{~km}$ ENE of Prosser \\
\hline
\end{tabular}


Table 3.2. (Contd.)

\begin{tabular}{|c|c|c|c|c|c|c|c|c|c|c|c|c|c|}
\hline Event ID & Type & Date & Time & Latitutde & "Longitude & Depth & Mag & MS/NP & Gap & Dmin & $\overline{\text { RMS }}$ & $\overline{\mathbf{Q}}$ & "Location \\
\hline 03050723025 & $\mathrm{P}$ & $03 / 05 / 07$ & $23: 03: 21.28$ & $40 \mathrm{~N} 15.15$ & $119 \mathrm{~W} 27.76$ & 3.45 & & $7 / 07$ & 221 & 5 & 0.03 & AD & 13.6 km WSW of Richland \\
\hline 03051122571 & & $03 / 05 / 11$ & $22: 57: 31.91$ & $46 \mathrm{~N} 29.02$ & $119 \mathrm{~W} 29.25$ & 15.21 & -0.5 & $9 / 12$ & 61 & 10 & 0.04 & AA & $9.2 \mathrm{~km} \mathrm{SSE}$ of 200 East \\
\hline 03051222515 & $\mathrm{P}$ & $03 / 05 / 12$ & $22: 52: 19.33$ & $46 \mathrm{~N} 13.43$ & $119 \mathrm{~W} 25.51$ & 6.96 & & $3 / 05$ & 332 & 8 & 0.03 & $\mathrm{BD}$ & $12.2 \mathrm{~km} \mathrm{WSW}$ of Richland \\
\hline 03051404592 & & $03 / 05 / 14$ & $04: 59: 43.65$ & $46 \mathrm{~N} 07.00$ & $119 \mathrm{~W} 47.70$ & 22.38 & 1.7 & $25 / 27$ & 126 & 13 & 0.09 & $\mathrm{AB}$ & $10.3 \mathrm{~km} \mathrm{SSW}$ of Prosser \\
\hline 03051422413 & $\mathrm{P}$ & $03 / 05 / 14$ & $22: 41: 46.81$ & $46 \mathrm{~N} 16.37$ & $119 \mathrm{~W} 27.49$ & 2.83 & & $4 / 04$ & 285 & 3 & 0.00 & $\mathrm{AD}$ & $12.9 \mathrm{~km} \mathrm{~W}$ of Richland \\
\hline 03052309465 & & $03 / 05 / 23$ & $09: 47: 13.57$ & $46 \mathrm{~N} 21.60$ & 119W39.92 & 8.70 & 0.1 & $5 / 07$ & 176 & 6 & 0.03 & $\mathrm{AD}$ & $18.8 \mathrm{~km}$ NNE of Prosser \\
\hline 03052400584 & & $03 / 05 / 24$ & $00: 59: 12.40$ & $46 \mathrm{~N} 20.16$ & $119 \mathrm{~W} 41.10$ & 4.40 & 0.3 & $11 / 13$ & 169 & 9 & 0.12 & $\mathrm{AC}$ & $15.7 \mathrm{~km}$ NNE of Prosser \\
\hline 03052502524 & & $03 / 05 / 25$ & $02: 52: 57.28$ & $46 \mathrm{~N} 33.07$ & $119 \mathrm{~W} 11.52$ & 0.78 & -0.4 & $5 / 06$ & 289 & 21 & 0.28 & $\mathrm{BD}$ & $18.2 \mathrm{~km} \mathrm{NE}$ of 400 Area \\
\hline 03052521244 & & $03 / 05 / 25$ & $21: 25: 08.00$ & $46 \mathrm{~N} 44.73$ & 119W21.77 & 4.05 & 0.4 & $16 / 19$ & 96 & 6 & 0.09 & $\mathrm{AB}$ & $17.5 \mathrm{~km} \mathrm{WSW}$ of Othello \\
\hline 03052914484 & & $03 / 05 / 29$ & $14: 49: 11.62$ & $46 \mathrm{~N} 09.47$ & $119 \mathrm{~W} 41.87$ & 8.61 & 1.1 & $15 / 15$ & 166 & 6 & 0.07 & $\mathrm{AC}$ & 7.7 km SE of Prosser \\
\hline 03060404453 & & $03 / 06 / 04$ & 04:45:51.85 & $46 \mathrm{~N} 04.24$ & $119 \mathrm{~W} 14.16$ & 12.42 & 0.5 & $9 / 09$ & 219 & 21 & 0.06 & $\mathrm{AD}$ & 17.1 km SSW of Kennewick \\
\hline 03060623154 & $\mathrm{P}$ & $03 / 06 / 06$ & $23: 16: 07.18$ & $46 \mathrm{~N} 14.18$ & $119 \mathrm{~W} 27.13$ & 3.52 & & $9 / 10$ & 231 & 6 & 0.11 & $\mathrm{AD}$ & $13.4 \mathrm{~km} \mathrm{WSW}$ of Richland \\
\hline 03060801020 & & $03 / 06 / 08$ & 01:02:27.86 & $46 \mathrm{~N} 20.09$ & $119 \mathrm{~W} 41.68$ & 2.93 & 0.6 & $11 / 15$ & 173 & 10 & 0.10 & $\mathrm{BC}$ & $15.3 \mathrm{~km}$ NNE of Prosser \\
\hline 03061310095 & & $03 / 06 / 13$ & $10: 10: 15.17$ & $46 \mathrm{~N} 18.83$ & 119W39.57 & 6.47 & -0.4 & $6 / 09$ & 298 & 10 & 0.19 & $\mathrm{CD}$ & $14.5 \mathrm{~km} \mathrm{NE}$ of Prosser \\
\hline 03061310103 & & $03 / 06 / 13$ & $10: 10: 55.36$ & $46 \mathrm{~N} 20.19$ & 119W40.41 & 4.63 & 0.4 & $12 / 15$ & 120 & 9 & 0.17 & $\mathrm{BB}$ & $16.1 \mathrm{~km}$ NNE of Prosser \\
\hline 03061422131 & & $03 / 06 / 14$ & $22: 13: 32.82$ & $46 \mathrm{~N} 20.19$ & $119 \mathrm{~W} 41.47$ & 3.82 & 0.2 & $7 / 08$ & 171 & 10 & 0.07 & $\mathrm{AC}$ & $15.6 \mathrm{~km}$ NNE of Prosser \\
\hline 03061815363 & & $03 / 06 / 18$ & $15: 36: 59.79$ & $46 \mathrm{~N} 20.30$ & $119 \mathrm{~W} 40.59$ & 6.27 & 0.1 & $4 / 06$ & 286 & 9 & 0.09 & $\mathrm{BD}$ & $16.2 \mathrm{~km}$ NNE of Prosser \\
\hline 03061815384 & & $03 / 06 / 18$ & 15:39:06.34 & $46 \mathrm{~N} 18.77$ & $119 \mathrm{~W} 43.08$ & 6.31 & 0.0 & $6 / 08$ & 265 & 13 & 0.14 & $\mathrm{CD}$ & $12.4 \mathrm{~km}$ NNE of Prosser \\
\hline 03061917520 & & $03 / 06 / 19$ & $17: 52: 22.79$ & $46 \mathrm{~N} 19.54$ & $119 \mathrm{~W} 41.17$ & 5.84 & 0.0 & $5 / 07$ & 254 & 10 & 0.11 & $\mathrm{BD}$ & $14.6 \mathrm{~km}$ NNE of Prosser \\
\hline 03062314213 & & $03 / 06 / 23$ & $14: 21: 58.47$ & $46 \mathrm{~N} 20.21$ & $119 \mathrm{~W} 41.37$ & 4.04 & 0.8 & $8 / 08$ & 171 & 9 & 0.11 & $\mathrm{BC}$ & $15.7 \mathrm{~km}$ NNE of Prosser \\
\hline 03062319242 & & $03 / 06 / 23$ & $19: 24: 42.71$ & $46 \mathrm{~N} 19.97$ & $119 \mathrm{~W} 41.10$ & 2.16 & 0.2 & $9 / 12$ & 169 & 9 & 0.08 & $\mathrm{BC}$ & $15.4 \mathrm{~km}$ NNE of Prosser \\
\hline 03062320515 & & $03 / 06 / 23$ & $20: 52: 17.88$ & $46 \mathrm{~N} 22.97$ & $119 \mathrm{~W} 19.08$ & 15.69 & -0.4 & $6 / 06$ & 199 & 5 & 0.11 & $\mathrm{BD}$ & $4.1 \mathrm{~km} \mathrm{NW}$ of 300 Area \\
\hline 03062423172 & & $03 / 06 / 24$ & $23: 17: 46.90$ & $46 \mathrm{~N} 26.69$ & $119 \mathrm{~W} 35.83$ & 15.14 & 0.2 & $13 / 15$ & 99 & 5 & 0.06 & $\mathrm{AB}$ & $13.0 \mathrm{~km} \mathrm{SSE}$ of $200 \mathrm{West}$ \\
\hline 03062423575 & & $03 / 06 / 24$ & $23: 58: 19.70$ & $46 \mathrm{~N} 20.17$ & $119 \mathrm{~W} 40.89$ & 6.22 & 0.0 & $6 / 07$ & 167 & 9 & 0.13 & $\mathrm{BC}$ & $15.8 \mathrm{~km} \mathrm{NNE}$ of Prosser \\
\hline 03062500251 & & $03 / 06 / 25$ & $00: 25: 35.03$ & $46 \mathrm{~N} 20.09$ & $119 \mathrm{~W} 40.62$ & 6.05 & 1.4 & $25 / 27$ & 121 & 9 & 0.14 & $\mathrm{AB}$ & $15.9 \mathrm{~km} \mathrm{NNE}$ of Prosser \\
\hline 03062509421 & & $03 / 06 / 25$ & 09:42:33.06 & $46 \mathrm{~N} 20.86$ & 119W32.84 & 14.25 & 0.0 & $9 / 09$ & 202 & 5 & 0.03 & $\mathrm{AD}$ & $17.5 \mathrm{~km} \mathrm{WSW}$ of 400 Area \\
\hline 03062622340 & & $03 / 06 / 26$ & $22: 34: 25.16$ & $46 \mathrm{~N} 20.17$ & $119 \mathrm{~W} 40.52$ & 7.10 & $\begin{array}{ll}-0.1 \\
\end{array}$ & $3 / 06$ & 304 & 9 & 0.06 & $\mathrm{BD}$ & $16.0 \mathrm{~km} \mathrm{NNE}$ of Prosser \\
\hline 03062809530 & & $03 / 06 / 28$ & 09:53:21.46 & $46 \mathrm{~N} 19.98$ & $119 \mathrm{~W} 40.37$ & 5.37 & 0.5 & $7 / 07$ & 163 & 9 & 0.08 & $\mathrm{AC}$ & $15.8 \mathrm{~km}$ NNE of Prosser \\
\hline 03063003194 & & $03 / 06 / 30$ & 03:19:38.96 & $46 \mathrm{~N} 07.68$ & 119W07.62 & 0.04 & 1.0 & $5 / 07$ & 103 & 52 & 0.57 & DD & $8.4 \mathrm{~km} \mathrm{~S}$ of Kennewick \\
\hline
\end{tabular}




\section{Explanation of Table 3.2}

Event ID: The Earthworm Recording System creates the identification number. XPED uses the year, month, day and time to create a unique number for each event.

Type: $\quad \mathrm{P}$ is Probable Blast; $\mathrm{X}$ is Confirmed Blast; $\mathrm{F}$ is Felt Earthquake; $\mathrm{S}$ is surficial event (rockslide, avalanche) and not a explosion or tectonic earthquake; blank is local earthquake.

Date: The year and day of the year in Universal Time Coordinated (UTC). UTC is used throughout this report unless otherwise indicated.

Time: The origin time of the earthquake given in UTC. To covert UTC to Pacific Standard Time, subtract eight hours; to Pacific Daylight Time, subtract seven hours.

Latitude: North latitude, in degrees and minutes, of the earthquake epicenter.

Longitude: West longitude, in degrees and minutes, of the earthquake epicenter.

Depth: The depth of the earthquake in kilometers $(\mathrm{km})$.

Mag: $\quad$ The magnitude is expressed as Coda-Length magnitude $\mathrm{M}_{\mathrm{c}}$, an estimate of local magnitude $\mathrm{M}_{\mathrm{L}}$ (Richter 1958). If magnitude is blank a determination was not made.

NS/NP: Number of stations/number of phases used in the solutions.

Gap: Azimuthal gap. The largest angle (relative to the epicenter) containing no stations.

DMIN: The distance from the earthquake epicenter to the closest station

RMS: $\quad$ The root-mean-square residual (observed arrival times minus the predicted arrival times) at all stations used to locate the earthquake. It is only useful as a measure of quality of the solution when five or more well-distributed stations are used in the solution. Good solutions are normally characterized by RMS values of less than about 0.3 seconds.

Q: $\quad$ The Quality Factors indicate the general reliability of the solution/location (A is best quality, D is worst). See Section 3.3 of this report: Quality Factors.

\subsection{Quality Factors (Q)}

XPED assigns a two-letter Quality factor (Table 3.2) that indicates the general reliability of the solution (A is best quality, $\mathbf{D}$ is worst). Similar quality factors are used by the USGS for events located with the computer program HYPO71. The first letter of the quality code is a measure of the hypocenter quality based primarily on travel time residuals. For example: Quality A requires a root-mean-square residual (RMS) less than 0.15 seconds while a RMS of 0.5 seconds or more is $\mathbf{D}$ quality (other estimates of the location uncertainty also affect this quality parameter). The second letter of the quality code is related to the spatial distribution of stations that contribute to the event's location, including the number 
of stations (NS), the number of p-wave and s-wave phases (NP), the largest gap in event-station azimuth distribution (GAP), and the closest distance from the epicenter to a station (DMIN). Quality A requires a solution with $\mathbf{N P}>8, \mathbf{G A P}<90^{\circ}$, and $\mathbf{D M I N}<5 \mathrm{~km}$ (or the hypocenter depth if it is greater than $5 \mathrm{~km}$ ). If $\mathbf{N P} \leq 5, \mathbf{G A P}>180^{\circ}$, or DMIN $>50 \mathrm{~km}$, the solution is assigned Quality $\mathbf{D}$. 


\subsection{Geology and Tectonic Analysis}

The Hanford Site lies within the Columbia Basin, which is an intermontane basin between the Cascade Range and the Rocky Mountains that is filled with Cenozoic volcanic rocks and sediments. This basin forms the northern part of the Columbia Plateau physiographic province (Fenneman 1931) and the Columbia River flood-basalt province (Reidel and Hooper 1989). In the central and western parts of the Columbia Basin, the Columbia River Basalt Group (CRBG) overlies Tertiary continental sedimentary rocks and is overlain by late Tertiary and Quaternary fluvial and glaciofluvial deposits (Campbell 1989; Reidel et al. 1989, 1994; DOE 1988). In the eastern part, a thin $(<100 \mathrm{~m})$ sedimentary unit separates the basalt and underling crystalline basement and a thin $(<10 \mathrm{~m})$ veneer of eolian sediments overlies the basalt (Reidel et al. 1989, 1994).

The Columbia Basin has two structural subdivisions or subprovinces: the Yakima Fold Belt and the Palouse Slope. The Yakima Fold Belt includes the western and central parts of the Columbia Basin and is a series of anticlinal ridges and synclinal valleys with major thrust faults along the northern flanks (Figure 4.1) (Reidel and Fecht 1994a, 1994b). The Palouse Slope is the eastern part of the basin and is less deformed than the Yakima Fold Belt with only a few faults and low amplitude, long wavelength folds on an otherwise gently westward dipping paleoslope. Figure 4.2 shows north-south and east-west cross sections through the Columbia Basin based on surface mapping (Reidel and Fecht 1994a, 1994b), deep boreholes (Reidel et al. 1994), geophysical data (Rohay et al. 1985; DOE 1988), and magnetotelluric data obtained as part of BWIP (DOE 1988).

\subsection{Earthquake Stratigraphy}

Studies of seismicity at the Hanford Site have shown that the seismic activity is related to crustal stratigraphy (layers of rock types) (Rohay et al. 1985; DOE 1988). The main geologic units important to earthquakes at Hanford and the surrounding area are:

- The Miocene Columbia River Basalt Group (CRBG)

- Pre-basalt sediments of Paleocene, Eocene, and Oligocene age

- The crystalline basement consisting of 2 layers composed of Precambrian and Paleozoic craton

- Mesozoic accreted terranes.

\subsection{Geologic Structure Beneath the Monitored Area}

Between the late 1950s and the early 1980s, deep boreholes were drilled for hydrocarbon exploration in the Columbia Basin. These boreholes provided accurate measurements of the physical properties of the CRBG and the pre-basalt sediments (Reidel et al. 1989, 1994), but the thickness of the pre-basalt sediments and nature of the crystalline basement are still poorly understood. The difference between the thicknesses listed in Table 4.1 and the thicknesses of the crustal layers in the velocity model in Table 3.1 reflect data specific to UW's crustal velocity model for eastern Washington. Table 4.1 is derived from Reidel et al. (1994) and was developed for the geologic interpretation in this report. The thicknesses of these units are variable across the monitored area. Table 4.1 summarizes the approximate thickness at the borders of the monitored area. 


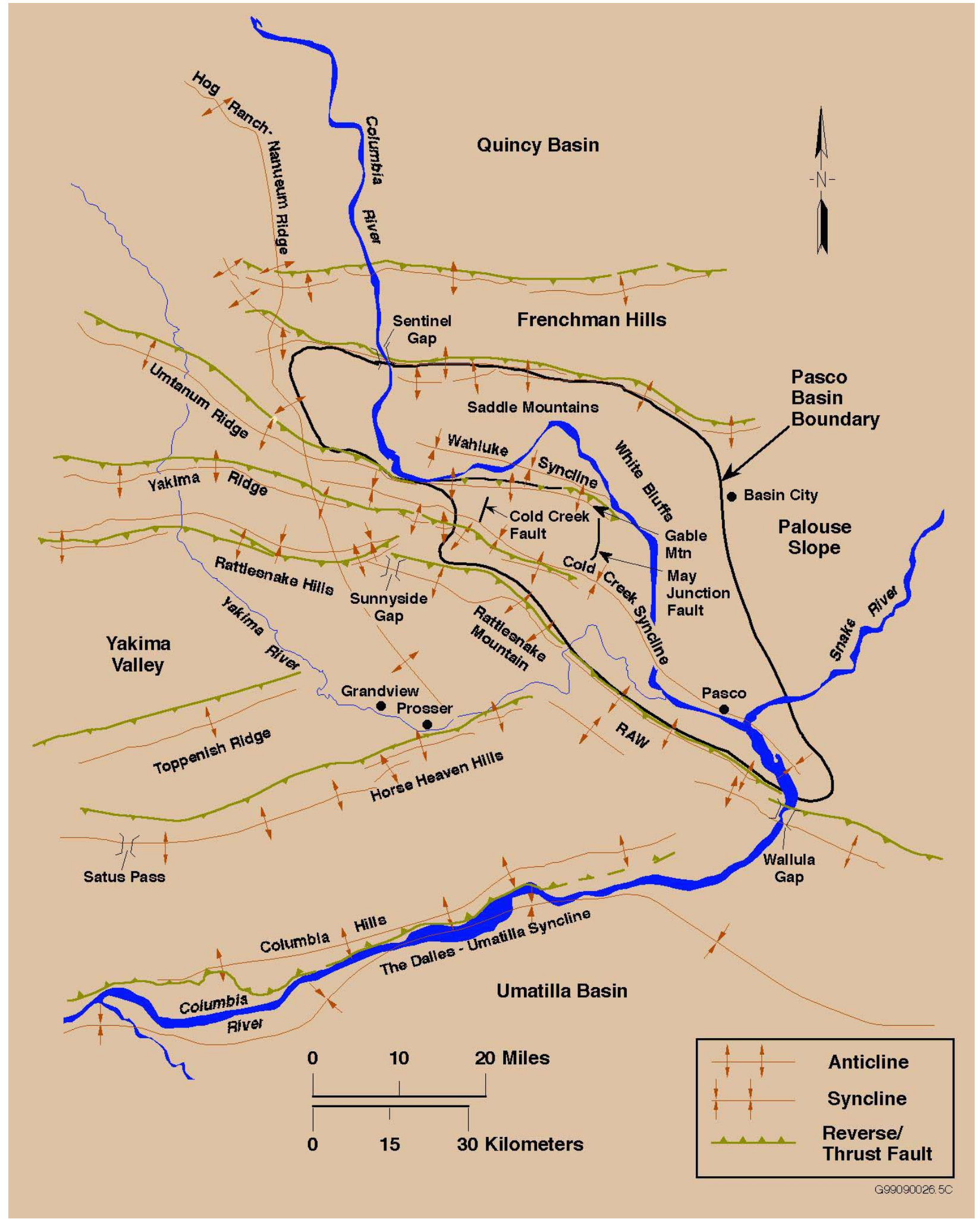

Figure 4.1. Tectonic Map of Columbia Basin Showing Major Seismic Source Structures 

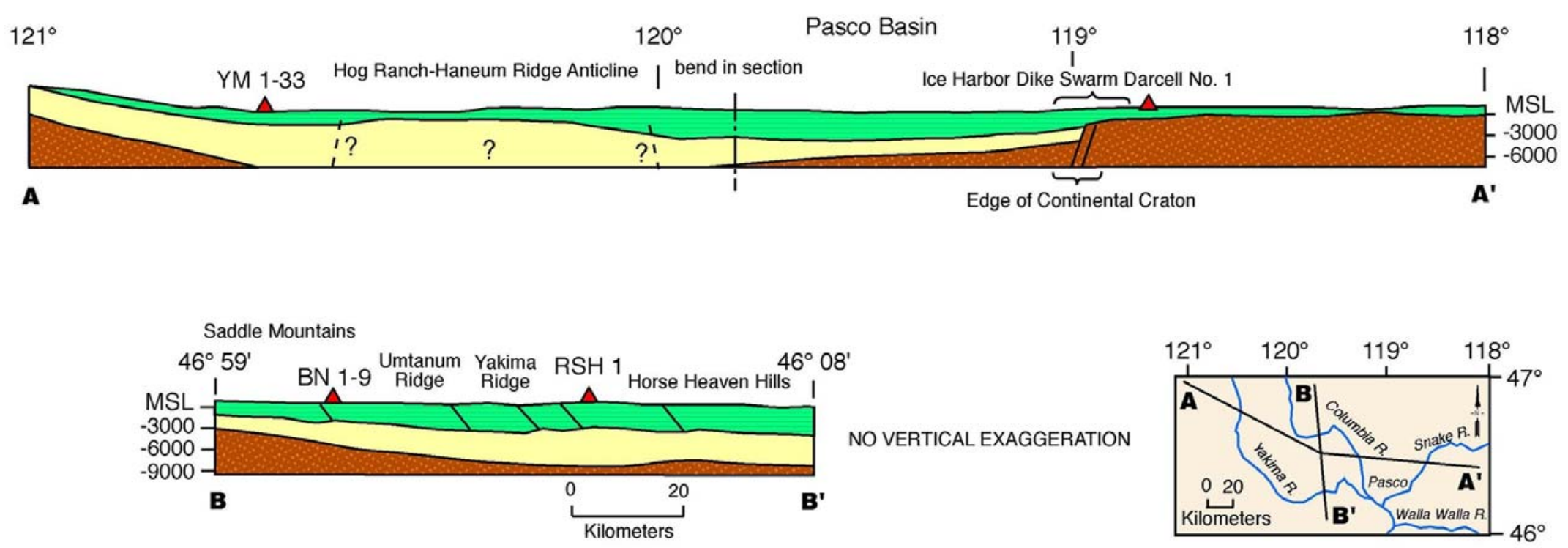

$\Delta$ Hydrocarbon exploration borehole

Columbia River Basalt Group

Tertiary sediments

Basement rock

Figure 4.2. Geologic Cross Sections Through the Columbia Basin (Reidel et al. 1994) 
Table 4.1. Thicknesses of Stratigraphic Units in the Monitoring Area

\begin{tabular}{||l|c|c|c|c||}
\hline \multicolumn{1}{|c|}{ Stratigraphy } & North & South & East & West \\
\hline \hline Columbia River Basalt Group (includes suprabasalt sediments) & $3.0 \mathrm{~km}$ & $4.5 \mathrm{~km}$ & $2.2 \mathrm{~km}$ & $4.2 \mathrm{~km}$ \\
\hline Pre-basalt Sediments & $3.0 \mathrm{~km}$ & $>4.5 \mathrm{~km}$ & 0 & $>6.0 \mathrm{~km}$ \\
\hline
\end{tabular}

The thickness of the basalt and the pre-basalt sediments varies as a result of different tectonic environments. The western edge of the North American craton (late Precambrian/Paleozoic continental margin and Precambrian craton) is located in the eastern portion of the monitored area (Reidel et al. 1994). The stratigraphy on the craton consists of CRBG overlying crystalline basement; the crystalline basement is continental crustal rock that underlies much of the western North America. The stratigraphy west of the craton consists of 4 to $5 \mathrm{~km}$ of CRBG overlying at least $6 \mathrm{~km}$ of pre-basalt sediments. This in turn overlies accreted terranes of Mesozoic age. The area west of the craton was subsiding during the Eocene and Oligocene, accumulating great thickness of pre-CRBG sediments. Continued subsidence in this area during the Miocene resulted in thicker CRBG compared to that on the craton. Subsidence continues today but at a greatly reduced rate (Reidel et al. 1994).

\subsection{Tectonic Pattern}

Studies have concluded that earthquakes can occur in the following six different tectonic environments (earthquake sources) at the Hanford Site (Geomatrix 1996).

- Major Geologic Structures. Reverse/thrust faults in the CRBG associated with major anticlinal ridges such as Rattlesnake Mountain, Yakima Ridge, and Umtanum Ridge could produce some of the largest earthquakes.

- Secondary faults. These faults are typically smaller $(1-20 \mathrm{~km})$ than the main reverse/thrust faults that occur along the major anticlinal ridges (up to $100 \mathrm{~km}$ ). Secondary faults can be segment boundaries (tear faults) and small faults of any orientation that formed along with the main structure.

- Swarm areas. Small geographic areas not known to contain any geologic structures produce clusters of events (swarms), usually in the CRBG in synclinal valleys. These clusters consist of a series of small shocks with no outstanding principal event. Swarms occur over a period of days or months and the events may number into the hundreds and then quit, only to start again at a later date. This differs from the sequence of foreshocks, mainshock, and trailing-off aftershocks that have the same epicenter or are associated with the same fault system. In the past, swarms were thought to occur only in the Columbia River Basalt Group. Most swarm areas are in the basalt but swarm events also appear to occur in all geologic layers. However, typically a swarm event at a specific time is usually restricted to one layer. There are seven earthquake swarm areas that we recognize in the monitoring area (Figure 4.3) but this list will be updated as new swarm areas develop. The Saddle Mountains swarm area, Wooded Island swarm area, Wahluke swarm area, Coyote Rapids swarm area, and Horse Heaven Hills swarm area are typically active at one time or another during the year. The other earthquake swarm areas are active less frequently. 


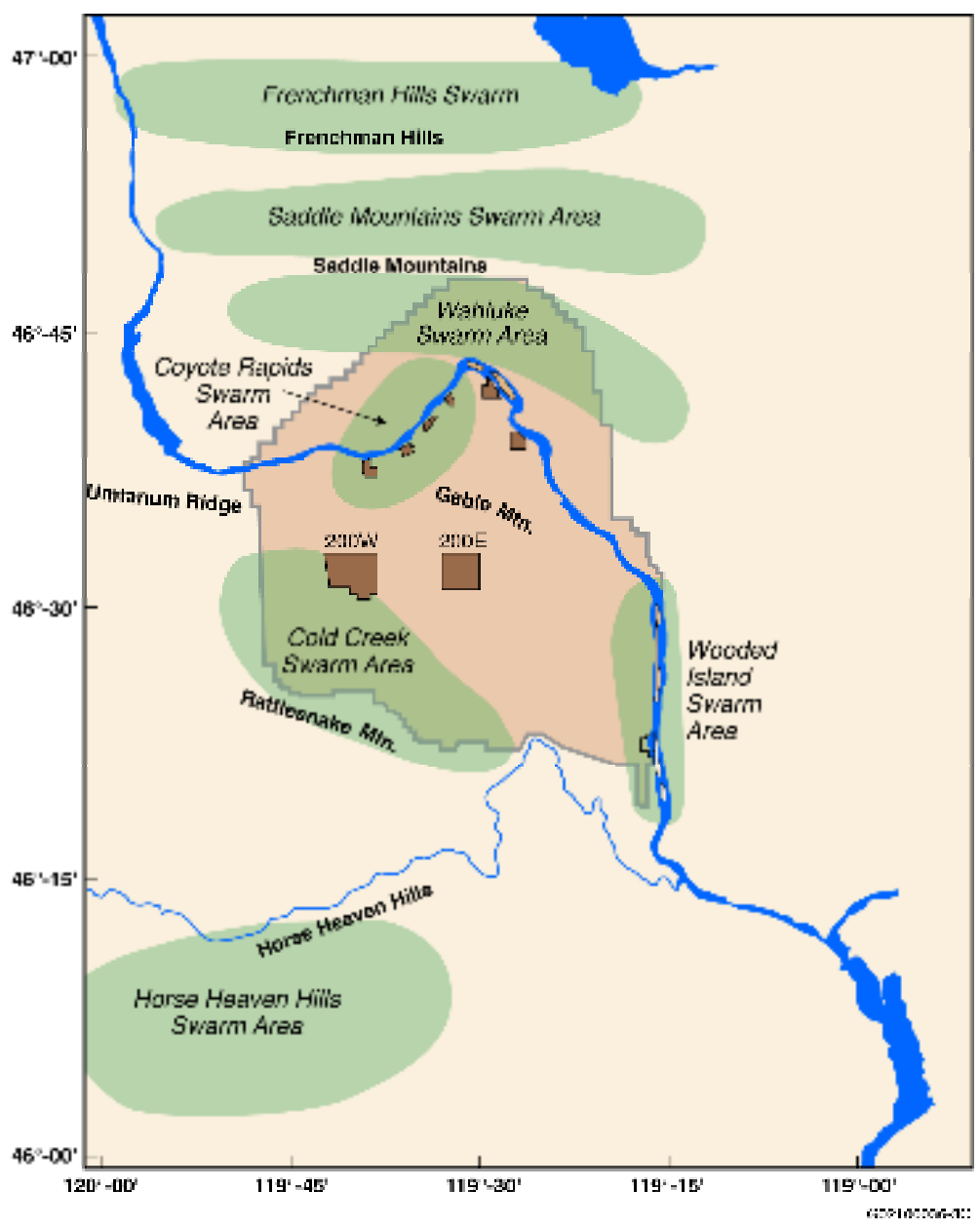

Figure 4.3. Locations of Known Earthquake Swarm Areas in the Hanford Monitoring Network Area

- The entire Columbia Basin. The entire basin, including the Hanford Site, could produce a "floating" earthquake. A floating earthquake is one that, for seismic design purposes, can happen anywhere in a tectonic province and is not associated with any known geologic structure. Seismic Monitoring classifies it as a random event for purposes of seismic design and vibratory ground motion studies.

- Basement source structures. Studies (Geomatrix 1996) suggest that major earthquakes can originate in tectonic structures in the crystalline basement. Because little is known about geologic structures in the crystalline basement beneath the Hanford Site, earthquakes cannot be directly tied to a mapped fault. Earthquakes occurring in the crystalline basement without known sources are treated as random events.

- The Cascadia Subduction Zone. This source has been postulated to be capable of producing a magnitude 9 earthquake. Because this source is along the western boundary of Washington State and outside the HSN, the Cascadia Subduction Zone is not an earthquake source that is monitored at the 
Hanford Site, so subduction zone earthquakes are not reported here. Because any earthquake along the Cascadia Subduction zone can have a significant impact on the Hanford Site or can be felt like the February 2001 Nisqually earthquake, UW monitors and reports on this earthquake source for the DOE. Ground motion from any moderate or larger Cascadia Subduction Zone earthquake is detected by Hanford SMAs and reported (see Section 5.0).

\subsection{Depth of Earthquakes}

Since records have been kept, most of the earthquakes at the Hanford Site have originated in the CRBG layer. The crystalline basement has had the next greatest amount of earthquakes followed by the pre-basalt sediments. The stratigraphic units for local earthquakes recorded during the first, second and third quarters of FY 2003 are listed in Table 4.2.

\subsection{Tectonic Activity}

\subsubsection{Third Quarter Summary}

Thirty-four earthquakes occurred in the Hanford monitoring area during the third quarter of FY 2003 (April 1, 2003 through June 31, 2003) (Table 4.3) (Figure 4.4). This section summarizes the earthquake activity for that period of time. More detailed descriptions of this activity are given below.

Table 4.2. Number of Local Earthquakes Occurring in Stratigraphic Units

\begin{tabular}{||l|c|c|c|c|c||}
\hline \multicolumn{1}{|c|}{ Unit } & First Quarter & Second Quarter & Third Quarter & Fourth Quarter & FY 2003 \\
\hline \hline Basalt & 6 & 9 & 15 & - & $30(36 \%)$ \\
\hline Pre-basalt Sediments & 4 & 2 & 13 & - & $19(23 \%)$ \\
\hline Crystalline Basement & 19 & 9 & 6 & - & $34(41 \%)$ \\
\hline Total & 29 & 20 & 34 & - & 83 \\
\hline \hline
\end{tabular}

Table 4.3. Summary of Earthquake Locations for FY 2003

\begin{tabular}{|c|c|c|c|c|c|c|}
\hline \multicolumn{2}{|r|}{ Seismic Sources } & $\begin{array}{c}\text { First Quarter } \\
\text { 10/01- 12/30 }\end{array}$ & $\begin{array}{c}\text { Second Quarter } \\
1 / 01-3 / 31\end{array}$ & $\begin{array}{c}\text { Third Quarter } \\
4 / 01-6 / 30\end{array}$ & $\begin{array}{c}\text { Fourth Quarter } \\
7 / 01-9 / 30\end{array}$ & FY 2003 \\
\hline \multicolumn{2}{|c|}{ Geologic Structure } & 1 & 2 & 1 & - & $4(4.8 \%)$ \\
\hline \multirow{9}{*}{$\begin{array}{l}\text { Swarm } \\
\text { Areas }\end{array}$} & Frenchman Hills & 0 & 1 & 0 & - & $1(1.2 \%)$ \\
\hline & $\begin{array}{l}\text { Saddle Mountains/ } \\
\text { Royal Slope }\end{array}$ & 3 & 1 & 2 & - & $6(7.2 \%)$ \\
\hline & Coyote Rapids & 1 & 3 & 0 & - & $4(4.8 \%)$ \\
\hline & Wahluke Slope & 0 & 1 & 4 & - & $5(6.0 \%)$ \\
\hline & Wooded Island & 0 & 0 & 1 & - & $1(1.2 \%)$ \\
\hline & \begin{tabular}{|l} 
Cold Creek \\
\end{tabular} & 0 & 0 & 0 & - & 0 \\
\hline & Rattlesnake Mt. & 0 & 0 & 15 & & $15(18.1 \%)$ \\
\hline & Horse Heaven Hills & 2 & 0 & 0 & - & $2(2.4 \%)$ \\
\hline & Total for swarms & 6 & 6 & 22 & - & $34(41.0 \%)$ \\
\hline \multicolumn{2}{|c|}{ Random Events } & 22 & 12 & 11 & - & $45(54.2 \%)$ \\
\hline \multicolumn{2}{|c|}{ Total for all earthquakes } & 29 & 20 & 34 & - & 83 \\
\hline
\end{tabular}




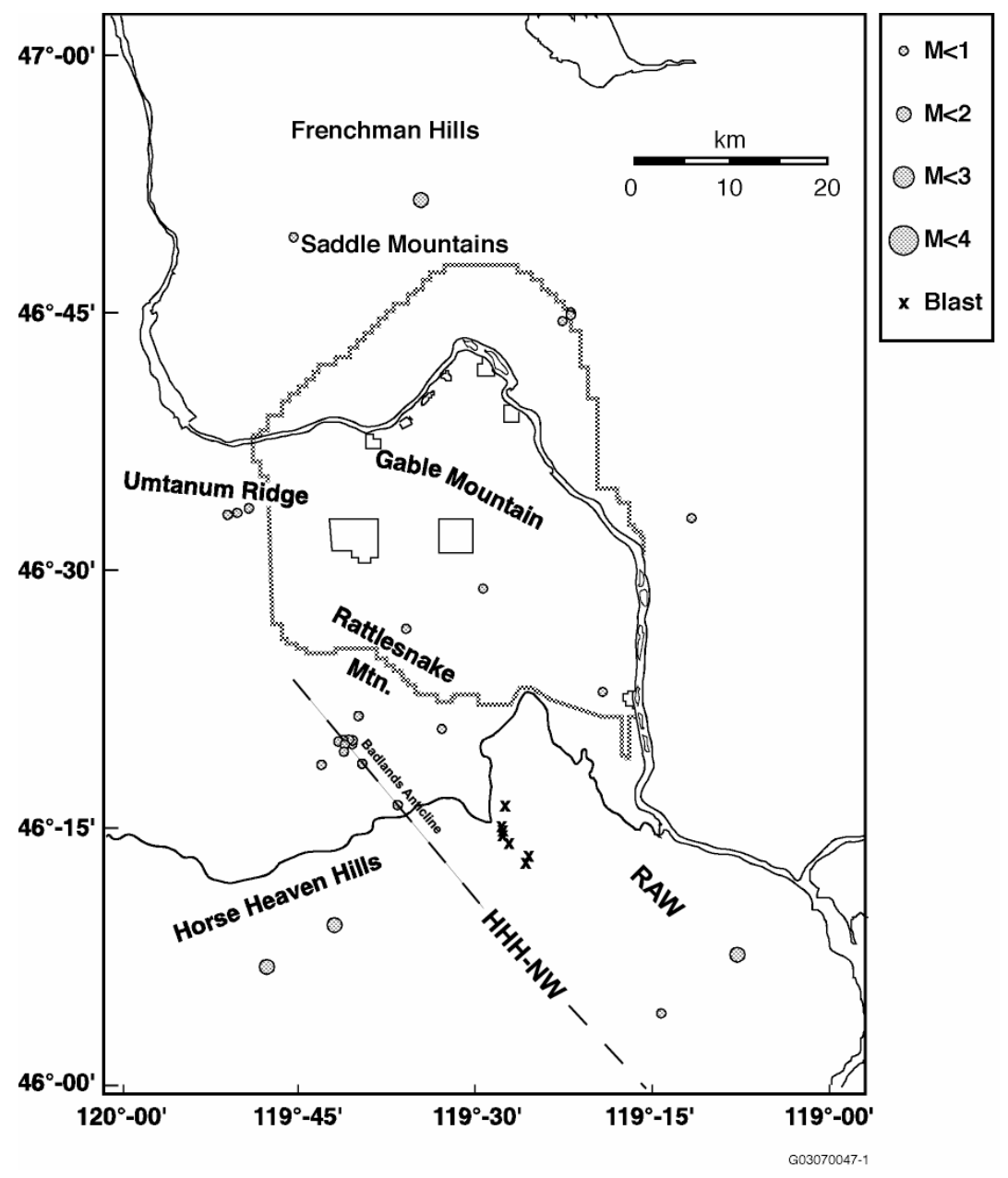

Figure 4.4. All Earthquakes Recorded in the Hanford Monitoring Area Between May 1, 2003 and June 30, 2003 (Coda Length Magnitude ( $\left.M_{c}\right)$ scale is shown at the side of the map). HHH-NW is the NW trend of the Horse Heaven Hills. RAW is the Rattlesnake Alignment-Wallula structural trend.

\subsubsection{Depth of Earthquakes}

During the third quarter of FY 2003, 15 (44\%) of the earthquakes occurred in the Columbia River Basalt Group, 13 (38\%) of the earthquakes occurred in the underlying pre-basalt sediments, and $6(18 \%)$ of the earthquakes occurred in the crystalline basement.

\subsubsection{Location of Earthquakes}

During the third quarter of FY 2003, 22 events (65\% of the earthquakes) were classified as swarm events. The Saddle Mountains, Wahluke Slope, and Wooded Island swarm areas were the active swarm areas. A new swarm started this quarter on the south slope of Rattlesnake Mountain. 
One event was classified as having some association with major geologic structures. This earthquake occurred in basalt and was along the Rattlesnake Alignment-Wallula structural trend (RAW Figure 4.1).

Eleven events (32\% of the earthquakes) were classified as random events. Earthquakes typically are classified as random if they occur below the Columbia River Basalt Group. Very little is known about geologic structures in the pre-basalt sediments and crystalline basement so any interpretations are speculative at this time. An earthquake also can be classified as a random event if it occurs in the basalt but is not located near any known geologic structure. During the third quarter, six events occurred in the crystalline basement. One random event occurred in the basalt and four events occurred in the pre-basalt sediments.

\subsubsection{Third Quarter Earthquakes of FY 2003}

\subsubsection{Major Anticlinal Ridges}

During the third quarter of FY 2003, we interpret one seismic event to have occurred on a major geologic structure. On June $30^{\text {th }}$, a small $\left(1.0 \mathrm{M}_{\mathrm{c}}\right)$, earthquake occurred in the basalt on a small doubly plunging anticline along the Rattlesnake Alignment - Wallula (RAW Figure 4.1) south of Kennewick, Washington.

\subsubsection{Earthquake Swarm Areas}

During the third quarter of FY 2003, we interpret 22 seismic events to have occurred in swarm areas (Figure 4.3). The Saddle Mountains, Coyote Rapids, Wahluke Slope, Wooded Island and Rattlesnake Mountain swarm areas were active.

\subsection{Saddle Mountains Swarm Area}

During the third quarter of FY 2003, two events occurred in the Saddle Mountains swarm area (Figure 4.4). The first event occurred on April $3^{\text {rd }}$ and had a magnitude of $0.3 \mathrm{M}_{\mathrm{c}}$. It occurred in the basalt and was at the same location where previous earthquakes had occurred on March $18^{\text {th }}, 2003$, October 12, 2002 and October 22, 2002. The second event occurred on April $8^{\text {th }}$ and had a magnitude $\left(\mathrm{M}_{\mathrm{c}}\right)$ of 1.8. This event occurred in the basalt near Smyrna Bench, which is east of the April $3^{\text {rd }}$ earthquake.

\subsection{Wahluke Slope Swarm Area}

Four small $\left(\mathrm{M}_{\mathrm{c}}<1\right)$ events occurred in the basalt in the Wahluke Slope swarm area during the third quarter. Three events occurred on May $5^{\text {th. }}$ The fourth event occurred on May $25^{\text {th }}$. These earthquakes occurred along the eastern edge of an area where earthquakes have occurred in the past several years. One event occurred there on March $9^{\text {th }}, 2003 ; 17$ events occurred there in 2001; and one event occurred there in 2002. 


\subsection{Wooded Island Swarm Area}

One small $\left(\mathrm{M}_{\mathrm{c}}<1\right)$ earthquake occurred in the Wooded Island swarm area on May $25^{\text {th }}$. The earthquake was in the basalt and on the northeast part of the swarm area in Ringold Coulee.

\subsection{Rattlesnake Mountain}

Between May $23^{\text {rd }}$ and June $28^{\text {th }}, 15$ small (all but $1 \mathrm{M}_{\mathrm{c}}<1$ ) events occurred on the south slope of Rattlesnake Mountain approximately $11 \mathrm{~km}$ from the crest of the anticline. These events occurred near the interface between the basalt and the pre-basalt sediments. The average depth was approximately 5 $\mathrm{km}$, which places them at the estimated base of the basalt. The swarm was centered over the northwest extension of the Horse Heaven Hills-NW anticline, locally called the 'badlands' anticline (Fig. 4.4) that is manifested at the surface as a low amplitude anticline. However, to the southwest, this structure forms the main NW portion of the Horse Heaven Hills anticline and thrust fault. The location of the swarm is also marked by the intersection of a small anticline with this portion of the Horse Heaven Hills-NW structural trend. This secondary anticline is thought to be confined to the upper layers of the basalt.

\subsubsection{Random or Floating Events}

During the third quarter of FY 2003, we interpret eleven random events to have occurred in the monitoring area. One was in the basalt, four were in pre-basalt sediments and six were in the crystalline basement. Events that occurred in the pre-basalt sediments and in the crystalline basement are typically classified as random events because there are no known geologic structures that have been identified in the rocks that occur below the Columbia River Basalt Group. However, we now recognize that some events that occur at depths that places them in the pre-basalt sediments and crystalline basement occur in patterns that fit our definition of earthquake swarms (Section 4.4). Those events are now reported in the appropriate sections on earthquake swarms.

From April $26^{\text {th }}$ through April $27^{\text {th }}$, three small $\left(\mathrm{M}_{\mathrm{c}}<1\right)$ earthquakes occurred along the Yakima Ridge trend west of the Hanford Site. The first two events were in the pre-basalt sediments and the last event was in the basalt. These events occurred about $3 \mathrm{~km}$ east of a similar type event from the second quarter of FY 2003 (February 16, 2003).

The next random event occurred on May $6^{\text {th }}$ and was small $\left(\mathrm{M}_{\mathrm{c}} 0.9\right)$. It occurred along the badlands anticline (Fig. 4.4) near the base of the basalt. This is the same geologic feature that the 15 Rattlesnake Mountain swarm events occurred on beginning on May $6^{\text {th }}$. The swarm events occurred approximately 4 $\mathrm{km}$ northwest of this event.

On May 11 and small $\left(\mathrm{M}_{\mathrm{c}} 0\right)$ event occurred in the crystalline basement east of the 200 Areas on Hanford.

Two earthquakes occurred near south of Prosser, Washington in May. The May $14^{\text {th }}$ event was in the crystalline basement and had a magnitude $\left(\mathrm{M}_{\mathrm{c}}\right)$ of 1.7 . The May $29^{\text {th }}$ event was in the pre-basalt 
sediments and had a magnitude $\left(\mathrm{M}_{\mathrm{c}}\right)$ of 1.1. Although both events occurred in the Horse Heaven Hills swarm area, because they were single events and below the basalt, they are classified as random events.

On June $4^{\text {th }}$ a small $\left(\mathrm{M}_{\mathrm{c}}<1.0\right)$ random event occurred in the crystalline basement in the portion of the Horse Heaven Hills (HHH-NW, Figure 4.4) south of Kennewick, Washington. No other events in the past several years have occurred near there.

A very small $\left(\mathrm{M}_{\mathrm{c}}\right.$ approx. 0$)$ random event occurred in the crystalline basement beneath the Cold Creek syncline on June $23^{\text {rd }}$.

On June $24^{\text {th }}$, a small $\left(\mathrm{M}_{\mathrm{c}}<1.0\right)$ event occurred in the crystalline basement south of the 200 Areas. This earthquake occurred near two events in the same area on November $4^{\text {th }}$ and $5^{\text {th }}, 2003$. All events were in the crystalline basement at about $15 \mathrm{~km}$ depth.

The final random event for the third quarter occurred on June $25^{\text {th }}$ in the crystalline basement. This event was very small (approx. $\mathrm{M}_{\mathrm{c}} 0$ ) and occurred beneath the southeast extension of Rattlesnake Mountain. Three events, October 8, and 28, and December 14, 2002, from the first quarter of FY 2003 occurred near this event. Two were in the crystalline basement and one in the pre-basalt sediments. 


\subsection{Strong Motion Accelerometer Operations}

The Hanford SMA network has been in continuous operation since November 20, 1998. The nominal threshold used in the SMA network is $0.001 \mathrm{~g}$ in order to provide ground motion for smaller, nondamaging earthquakes that can be useful in estimating the ground motion expected from larger earthquakes, and to confirm correct operation of the instruments by analyzing the smaller-amplitude triggers (see Section 2.2).

\subsection{Third Quarter of FY 2003 Triggers of the Hanford SMA Network}

The Hanford strong motion accelerometer network was not triggered by any seismic event during the third quarter of FY 2003. 


\subsection{Capabilities in the Event of a Significant Earthquake}

The SMA network was designed to provide ground motion data in areas at the Hanford Site that have high densities of people and/or facilities containing hazardous materials in order to insure the Hanford Site is in compliance with DOE Order 420.1, "Facility Safety." The network also allows Hanford Seismic Monitoring to support Hanford Site emergency services organizations in complying with DOE Order G 420.1-1, Section 4.7, "Emergency Preparedness and Emergency Communications," by providing area ground motion data in the event of an earthquake on the Hanford Site. This section summarizes the capabilities of the Seismic Monitoring Team in the event of an earthquake at Hanford.

\subsection{Use of the SMA Network in the Event of an Earthquake}

Historically, only a few facilities at the Hanford Site had instruments to provide data on peak ground accelerations or any type of ground motion. The present SMA instruments were located so that if an earthquake occurred, ground motion data would be readily available to assess the damage at the 100-K Area, the 200 East and West Areas, the 300 and 400 Area facilities, which have the greatest concentration of people and also contain hazardous materials (Moore and Reidel 1996).

Many facilities at the Hanford Site have undergone various degrees of seismic analysis either during design or during re-qualification. Although the seismic design of a building may be known, when an earthquake is "felt" in a facility on the Hanford Site, a determination must be made as to the extent of damage before it can be reoccupied and the systems restarted. A felt earthquake may not cause any significant damage to a building but, without adequate characterization of the ground motion, initial determination of the building's possibility of having damage may be impossible.

In the event of an earthquake such as the 2001 Nisqually earthquake, building managers, emergency directors, and engineers can obtain ground motion data recorded by the SMA network from the Seismic Monitoring Team in the Sigma V Building. This is done through the Hanford Site Emergency Services Organization. Normal hours of operation for the PNNL Seismic Monitoring Project are between 6 a.m. and 4:30 p.m., Monday through Friday. If a SMA is triggered, the Seismic Monitoring Team will download events that were recorded and determine the peak ground accelerations. This information is then passed on to Hanford Emergency Services personnel where the facility engineers can use the data to determine if the ground motion exceeded, is equal to, or is less than the building design. This, along with assessments from trained engineers, allows the facility manager to make a rapid and cost-effective determination on whether a building is safe to re-occupy or should not be used until it has been inspected in more detail. Buildings that have designs exceeding the recorded ground motion could be put back into service very quickly; buildings with designs that are very close to or less than measured ground motion could be given priority for onsite damage inspections. 


\subsection{References}

Campbell, N. P. 1989. "Structural and stratigraphic interpretation of rocks under the Yakima fold belt, Columbia Basin, based on recent surface mapping and well data." In S. P. Reidel and P. R. Hooper (eds.), Volcanism and Tectonism in the Columbia River Flood-Basalt Province Geological Society of America Special Paper 239, pp. 209-222.

Crosson, R. S. 1972. Small Earthquakes, Structure and Tectonics of the Puget Sound Region. Bulletin of the Seismological Society of America, 62(5):1133-1171.

DOE. 1988. Site Characterization Plan for the Reference Location, Hanford, Washington-Consultation Draft. Report DOE/RW-0164, Vol. 1, U.S. Department of Energy, Washington, D.C.

Fenneman, N. M. 1931. Physiography of western United States. McGraw-Hill, 534 p.

Geomatrix. 1996. Probabilistic Seismic Hazard Analysis, DOE Hanford Site, Washington. WHC-SDW236A-TI-002, Rev. 1, Westinghouse Hanford Company, Richland, Washington.

Moore, C. and S. P. Reidel. 1996. Hanford Site Seismic Monitoring Instrumentation Plan. WHC-SDGN-ER-30036, Westinghouse Hanford Company, Richland, Washington.

Reidel, S.P., 1988. Geologic Map of the Saddle Mountains, South-Central Washington. Washington Division of Geology and Earth Resources Geologic Map GM-38.

Reidel, S.P., 1984. The Saddle Mountains-The evolution of an anticline in the Yakima Fold Belt. American Journal of Science, v. 284, no. 8, p. 942-978.

Reidel, S. P. and K. R. Fecht. 1994a. Geologic Map of the Richland 1:100,000 Quadrangle, Washington. Washington Division of Geology and Earth Resources Open File Report 94-8, 21 p., 1 plate.

Reidel, S. P. and K. R. Fecht. 1994b. Geologic Map of the Priest Rapids 1:100,000 Quadrangle, Washington. Washington Division of Geology and Earth Resources Open File Report 94-13, 22 p., 1 plate.

Reidel, S. P. and P. R. Hooper (eds.). 1989. Volcanism and Tectonism in the Columbia River FloodBasalt Province Geological Society of America Special Paper 239, 386 p.

Reidel, S. P., N. P. Campbell, K. R. Fecht, and K. A. Lindsey. 1994. "Late Cenozoic Structure and Stratigraphy of South-Central Washington." In E. Cheney and R. Lasmanis (eds.), Regional Geology of Washington State, Washington Division of Geology and Earth Resources Bulletin 80, pp. 159-180, Olympia, Washington.

Reidel, S. P., K. R. Fecht, M. C. Hagood, and T. L. Tolan. 1989. "Geologic Development of the Central Columbia Plateau." In S. P. Reidel and P. R. Hooper (eds.), Volcanism and Tectonism in the Columbia River Flood-Basalt Province Geological Society of America Special Paper 239, pp. 247-264. 
Richter, C. F. 1958. Elementary Seismology, W. H. Freeman and Company, p. 768.

Rohay, A. C., D. W. Glover, and S. D. Malone. 1985. Time-Term Analysis of Upper Crustal Structure in the Columbia Basin, Washington. RHO-BW-SA-435 P, Rockwell Hanford Operations, Richland, Washington. 


\section{Distribution}

No. of

\section{Copies}

\section{OFFSITE}

G. Crawford

Earthquake Program Manager

Washington Emergency Management Division

Building 20, M/S: TA-20

Camp Murray, WA 98430-5122

J. Kimball

NA-53/Germantown Building

U.S. Department of Energy

1000 Independence Ave. SW

Washington, D.C. 20585-1290

S. Lilligren

Nez Perce Tribe

P.O. Box 365

Lapwai, ID 83540

J. Litehiser

Bechtel National, Inc.

P.O. Box 193965

San Francisco, CA 94119-3965

Administrator

Kennewick General Hospital

P.O. Box 6128

Kennewick, WA 99336

P. Rizzo

105 Mall Boulevard

Monroeville, PA 15146
No. of

Copies

3 Oregon Department of Geology and Mineral Industries

Suite 965, 800 NE Oregon Street \#28

Portland, OR 97232

ATTN: J. Beaulieu

Library

I. Madin

N. Rasmussen

3140 Ravenshoe Drive

Las Vegas, NV 89134

W. Riggsby

1216 W. Kennewick Avenue

Kennewick, WA 99336

M. Stickney

Montana Tech University

Earthquake Studies Office

Butte, MT 59701

A. Tallman 1940 Quail Court

West Richland, WA 99353

5 University of Washington

Geophysics Program

P.O. Box 351650

Seattle, WA 98195-1650

ATTN: R. Crosson

R. Ludwin

S. Malone

A. Qamar

R. Steele

Distr.1 
No. of

Copies

2 University of Washington

U.S. Geological Survey

P.O. Box 351650

Seattle, WA 98195

ATTN: C. Weaver

T. Yelin

2 U.S. Geological Survey

Mail Stop 977

345 Middlefield Road

Menlo Park, CA 94025

ATTN: H. Stenner

T. Brocher

U.S. Fish and Wildlife Service

3250 Port of Benton Boulevard

Richland, WA 99352

3 Washington Division of Geology and Earth Resources

P.O. Box 47007

Olympia, WA 98504-7007

ATTN: S. Palmer

T. Walsh

Library

Washington State University

Department of Geology

P.O. Box 643420

Pullman, WA 99164-2812

I. G. Wong

Woodward-Clyde Federal Services

500-12 ${ }^{\text {th }}$ Street, Suite 200

Oakland, CA 94607-4010

J. Zollweg

Boise State University

Department of Geosciences

Boise, ID 83725
No. of

Copies

Tom Conrads

Parsons Infrastructure \& Technology Group

1955 Jadwin Av.

Richland, WA 99352

\section{ONSITE}

\section{DOE Richland Operations Office}

$\begin{array}{ll}\text { K. L. Flynn } & \text { A6-35 } \\ \text { M. J. Furman } & \text { A6-38 } \\ \text { R. D. Hildebrand } & \text { A6-38 } \\ \text { L.F. Miller } & \text { H6-60 } \\ \text { M. R. Moreno } & \text { A5-55 } \\ \text { J. G. Morse } & \text { A6-38 } \\ \text { M. L. Talbot } & \text { A6-35 } \\ \text { K. M. Thompson } & \text { A6-38 }\end{array}$

3 Bechtel Hanford, Inc.
V. J. Cueno
$\mathrm{H} 0-18$
K. R. Fecht
$\mathrm{H} 0-02$
P. J. Mackey
$\mathrm{H} 0-13$

8 CH2M HILL Hanford Group, Inc.

D. D. Bachland $\quad$ S7-86

S. M. Faulk S7-86

J. R. Freeman-Pollard S0-11

$\begin{array}{ll}\text { D. T. Heimberger } & \text { R2-11 }\end{array}$

A. J. Knepp E6-35

F. M. Mann E6-35

J. J. Zach R1-49

Duratek Federal Services Hanford

$\begin{array}{ll}\text { R. T. Wilde E6-35 } & \text { E }\end{array}$ 
No. of

Copies

10 Fluor Hanford, Inc.

D. A. Arrigoni

B. R. Bowman

M. E. Brown

D. A. Conners

J. T. Curtis

S. A. Fargo

B.H. Ford

T. P. Morales

R. Whitehurst II

M. I. Wood

Stoller

S. Sobczyk
No. of

Copies

Washington State Department of Ecology

N2-40

$\mathrm{N} 2-56$

A3-05

T3-28

B3-15

H8-60

E6-35

A3-05

X3-78

H8-44

B2-62
J. Caggiano

B5-18

12 Pacific Northwest National Laboratory

M. V. Berriochoa

K9-56

J. S. Fruchter

K6-96

D. C. Hartshorn

K6-81

D. G. Horton

K6-81

W. J. Martin

K6-81

B. D. Moon

K9-55

P. E. Moore

P7-63

S. P. Reidel

K6-81

A. C. Rohay

K6-81

M. M. Valenta

P7-22

Hanford Technical Library (2)

P8-55 